\title{
Geologic Map of the Granite 7.5' Quadrangle, Lake and Chaffee Counties, Colorado
}

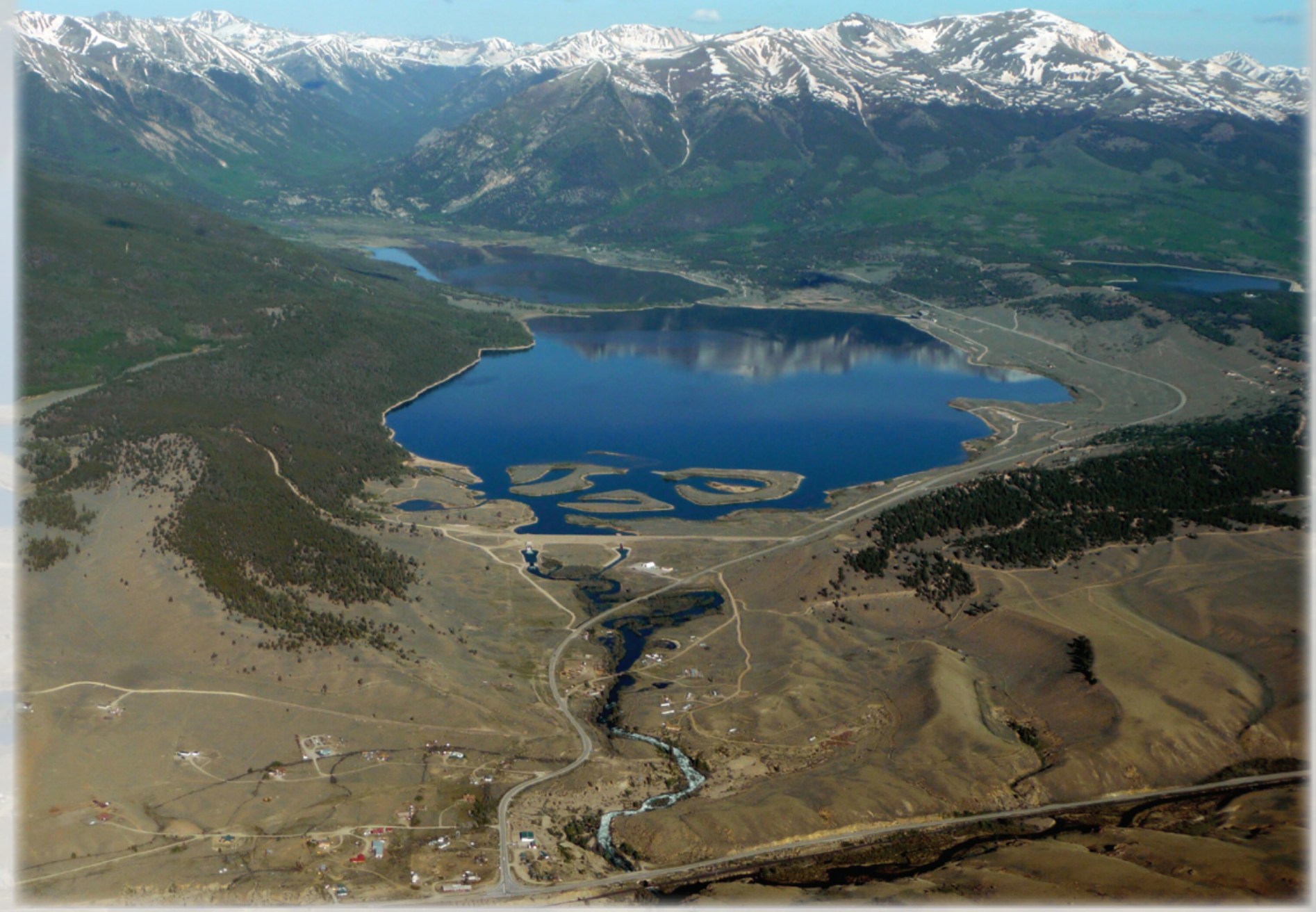

Pamphlet to accompany

Scientific Investigations Map 3294 
COVER. Oblique aerial view to the northwest looking toward the Twin Lakes Reservoir and the snow-capped peaks in the Sawatch Range. Highest peak on the skyline [far right] is Mount Elbert, $4,399 \mathrm{~m}(14,433 \mathrm{ft})$. Tree- and sagebrush-covered ridges on the south and north sides of the Twin Lakes reservoir are moraines composed of till of Pinedale, Bull Lake, and pre-Bull Lake age.

Arkansas River and US Highway 24 are in foreground. Photograph by Jason P. Briner, University at Buffalo, Buffalo, New York, June 8, 2010. 


\section{Geologic Map of the Granite 7.5' Quadrangle, Lake and Chaffee Counties, Colorado}

By Ralph R. Shroba, Karl S. Kellogg, and Theodore R. Brandt

Pamphlet to accompany

Scientific Investigations Map 3294 


\section{U.S. Department of the Interior \\ SALLY JEWELL, Secretary}

\section{U.S. Geological Survey \\ Suzette Kimball, Acting Director}

\section{U.S. Geological Survey, Reston, Virginia: 2014}

For more information on the USGS — the Federal source for science about the Earth, its natural and living resources, natural hazards, and the environment, visit http://www.usgs.gov or call 1-888-ASK-USGS.

For an overview of USGS information products, including maps, imagery, and publications, visit http://www.usgs.gov/pubprod

To order this and other USGS information products, visit http://store.usgs.gov

Any use of trade, firm, or product names is for descriptive purposes only and does not imply endorsement by the U.S. Government.

Although this information product, for the most part, is in the public domain, it also may contain copyrighted materials as noted in the text. Permission to reproduce copyrighted items must be secured from the copyright owner.

Suggested citation:

Shroba, R.R., Kellogg, K.S., and Brandt, T.R., 2014, Geologic map of the Granite 7.5' quadrangle, Lake and Chaffee Counties, Colorado: U.S. Geological Survey Scientific Investigations Map 3294, 31 p., 1 sheet, scale 1:24,000, http://dx.doi.org/10.3133/sim3294.

ISSN 2329-132X (online 


\section{Contents}

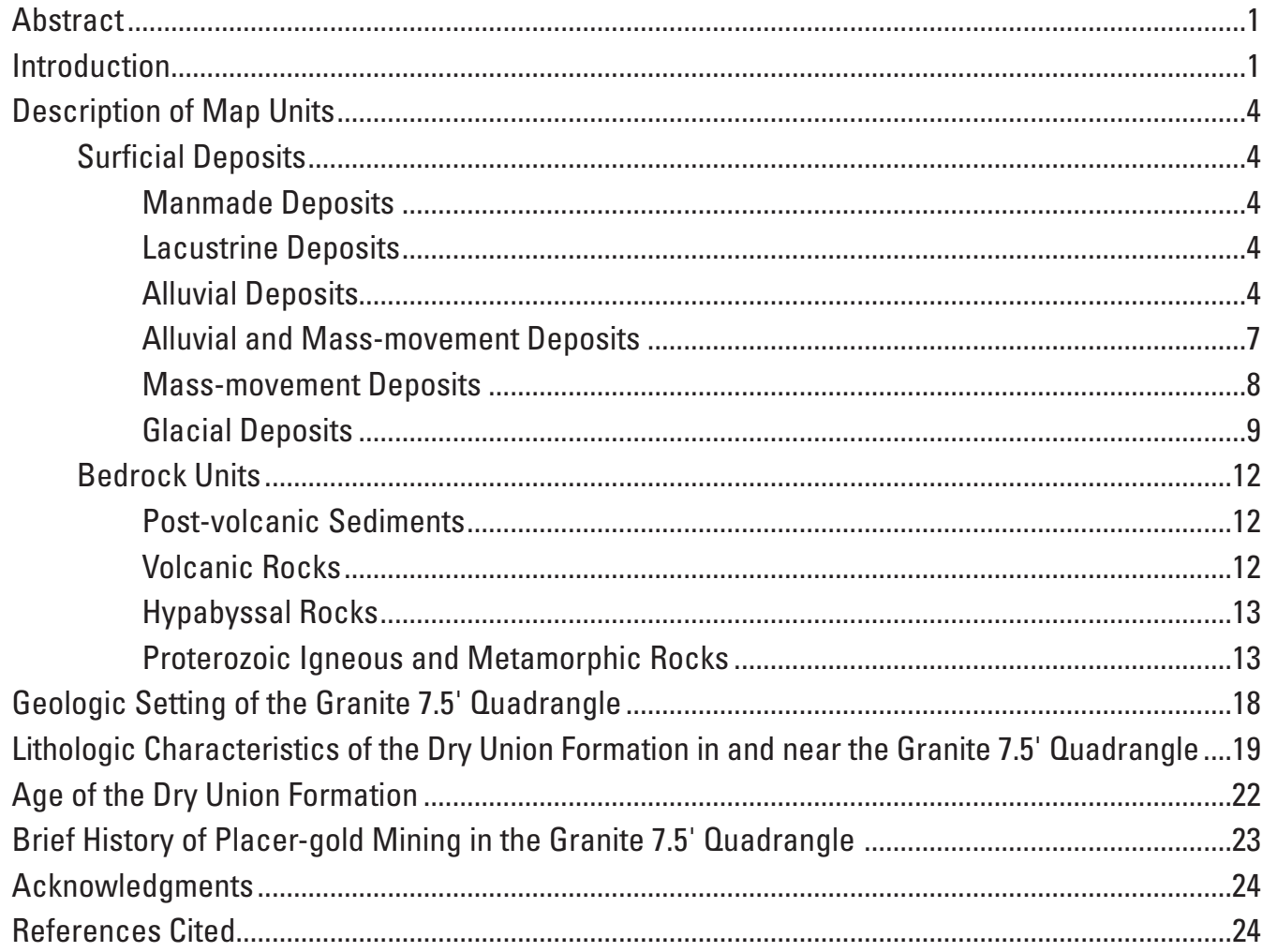

\section{Figures}

1. Area of Granite $7.5^{\prime}$ quadrangle covered by light detection and ranging (lidar)

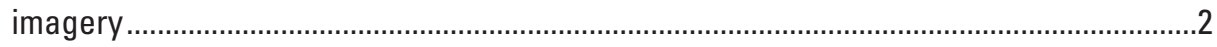

2. Geographic setting of the Granite $7.5^{\prime}$ quadrangle .......................................................16

\section{Sheet}

1. Geologic map of the Granite $7.5^{\prime}$ quadrangle, Lake and Chaffee Counties, Colorado ... link

\section{Tables}

1. Particle-size analyses of loess and till in and near the Granite $7.5^{\prime}$ quadrangle..............3

2. Approximate height, in meters, of the top of gravelly stream alluvium of middle Pleistocene to Holocene age above the Arkansas River..................................................17

3. Summary of isotopic ages for bedrock in the Granite 7.5' quadrangle ...........................17

4. Estimated particle sizes of unconsolidated to moderately consolidated sediments of the Dry Union Formation in the Granite 7.5' quadrangle 
5. Dry Munsell colors of unconsolidated to moderately consolidated sediments of the Dry Union Formation in the Granite 7.5' quadrangle.

6. Summary of mining methods, years of gold production, and estimated minimum total value of gold production. 


\section{Conversion Factors}

SI to Inch/Pound

\begin{tabular}{lll}
\hline Multiply & By & \multicolumn{1}{c}{ To obtain } \\
\hline centimeter $(\mathrm{cm})$ & Length & \\
millimeter $(\mathrm{mm})$ & 0.3937 & inch (in.) \\
meter $(\mathrm{m})$ & 0.03937 & inch (in.) \\
kilometer $(\mathrm{km})$ & 3.281 & foot (ft) \\
\hline & 0.6214 & mile (mi) \\
\hline square kilometer $\left(\mathrm{km}^{2}\right)$ & Area & square mile $\left(\mathrm{mi}^{2}\right)$ \\
\hline & 0.3861 & \\
\hline cubic meter per second $\left(\mathrm{m}^{3} / \mathrm{s}\right)$ & Flow rate & cubic foot per second $\left(\mathrm{ft}^{3} / \mathrm{s}\right)$ \\
\hline
\end{tabular}

Vertical coordinate information is referenced to the North American Vertical Datum of 1929 (NAVD 29)

Horizontal coordinate information is referenced to the North American Datum of 1927 (NAD 27)

Altitude, as used in this report, refers to distance above the vertical datum.

\section{Division of Quaternary, Neogene, and Paleogene Time used in this report ${ }^{1}$}

\begin{tabular}{llcc}
\hline Period or subperiod & Epoch & \multicolumn{1}{c}{ Age } \\
\hline \multirow{2}{*}{ Quaternary } & Holecene & & $0-11.7 \mathrm{ka}$ \\
& Pleistocene & late & $11.7-132 \mathrm{ka}$ \\
Neogene & & middle & $132-788 \mathrm{ka}$ \\
& & early & $788 \mathrm{ka}-2.588 \mathrm{Ma}$ \\
& Pliocene & & $2.588-5.332 \mathrm{Ma}$ \\
Paleogene & Miocene & & $5.332-23.03 \mathrm{Ma}$ \\
& Oligocene & & $23.03-33.9$ \\
& Eocene & & $33.9-55.8$ \\
& Paleocene & $55.8-65.5 \mathrm{Ma}$ \\
\hline
\end{tabular}

${ }^{1}$ Ages of time boundaries are those of the U.S. Geological Survey Geologic Names Committee (2010) except those for the late-middle Pleistocene boundary and middle-early Pleistocene boundary, which are those of Richmond and Fullerton (1986). Ages are expressed in ka for kilo-annum (thousand years) and Ma for mega-annum (million years).

\section{North American Land Mammal Ages used in this report ${ }^{1}$}

\begin{tabular}{lc}
\hline Land Mammal Age & Age \\
\hline Clarendonian & $8.9-11.6 \mathrm{Ma}$ \\
Barstovian & $11.6-15.9 \mathrm{Ma}$ \\
Hemingfordian & $15.9-19 \mathrm{Ma}$ \\
Arikareean & $19-29 \mathrm{Ma}$ \\
\hline
\end{tabular}

${ }^{1}$ Ages of time boundaries are those of Woodburne and Swisher (1995). 



\title{
Geologic Map of the Granite 7.5' Quadrangle, Lake and Chaffee Counties, Colorado
}

\author{
By Ralph R. Shroba, Karl S. Kellogg, and Theodore R. Brandt
}

\section{Abstract}

The geologic map of the Granite 7.5' quadrangle, Lake and Chaffee Counties, Colorado, portrays the geology in the upper Arkansas valley and along the lower flanks of the Sawatch Range and Mosquito Range near the town of Granite. The oldest rocks, exposed in the southern and eastern parts of the quadrangle, include gneiss and plutonic rocks of Paleoproterozoic age. These rocks are intruded by younger plutonic rocks of Mesoproterozoic age. Felsic hypabyssal dikes, plugs, and plutons, ranging in age from Late Cretaceous or Paleocene to late Oligocene, locally intruded Proterozoic rocks. A small andesite lava flow of upper Oligocene age overlies Paleoproterozoic rock, just south of the Twin Lakes Reservoir. Gravelly fluvial and fan deposits of the Miocene and lower Pliocene(?) Dry Union Formation are preserved in the post-30 Ma upper Arkansas valley graben, a northern extension of the Rio Grande rift. Mostly north-northwest-trending faults displace deposits of the Dry Union Formation and older rock units. Light detection and ranging (lidar) imagery suggests that two short faults, near the Arkansas River, may displace surficial deposits as young as middle Pleistocene.

Surficial deposits of middle Pleistocene to Holocene age are widespread in the Granite quadrangle, particularly in the major valleys and on slopes underlain by the Dry Union Formation. The main deposits are glacial outwash and postglacial alluvium; mass-movement deposits transported by creep, debris flow, landsliding, and rockfall; till deposited during the Pinedale, Bull Lake, and pre-Bull Lake glaciations; rock-glacier deposits; and placer-tailings deposits formed by hydraulic mining and other mining methods used to concentrate native gold.

Hydrologic and geologic processes locally affect use of the land and locally may be of concern regarding the stability of buildings and infrastructure, chiefly in low-lying areas along and near stream channels and locally in areas of moderate to steep slopes. Low-lying areas along major and minor streams are subject to periodic stream flooding. Massmovement deposits and deposits of the Dry Union Formation that underlie moderate to steep slopes are locally subject to creep, debris-flow deposition, and landsliding. Proterozoic rocks that underlie steep slopes are locally subject to rockfall.

Sand and gravel resources for construction and other uses in and near the Granite quadrangle are present in outwashterrace deposits of middle and late Pleistocene age along the Arkansas River and along tributary streams in glaciated valleys.

\section{Introduction}

Surficial deposits within the Granite 7.5' quadrangle record alluvial, glacial, mass-movement, and lacustrine processes along the eastern flank of the Sawatch Range, upper Arkansas River valley, and the west flank of the Mosquito Range during the Quaternary. The quadrangle contains one of the most complete sequences of glacial till and outwash in central Colorado. These deposits and their associated landforms have been the subject of reconnaissance studies and detailed investigations since the early 1870s (Hayden, 1874; Capps and Leffingwell, 1904; Davis, 1905; Westgate, 1905; Capps, 1909; Ray, 1940; Richmond and Tweto, 1965; Tweto and Case, 1972; Shroba, 1977; Nelson and Shroba, 1998).

Many of the surficial deposits and deposits of the Dry Union Formation $(\mathrm{Nd})$ are poorly exposed within the map area. Deposits that are limited in extent were not mapped, including fill material along most roads and at most building sites, small deposits of placer tailings, and thin discontinuous colluvial deposits that commonly mantle the Paleogene and older bedrock units. Fractional map symbols (Qsw/Nd and Qc/Nd) are used to show where thin deposits of sheetwash alluvium or colluvium mantle sediments of the Dry Union Formation (Nd). These fractional units are defined in the descriptions of individual units that compose the fractional units, and are not shown on the correlation of map unit diagram.

The surficial units on this map are informal allostratigraphic units (disconformity-bound sequences) of the North American Stratigraphic Code (North American Commission on Stratigraphic Nomenclature, 2005), whereas the other map units (bedrock units) are formal lithostratigraphic or informal lithodemic units. 
Ages for surficial deposits within the map area are based chiefly on the following: relative heights of alluvial deposits above present stream channels, spatial relationships among glacial till and outwash deposits, relative degree of erosional modification of depositional landforms, degree of soil development on landforms, and clast weathering on and in deposits (see Nelson and Shroba, 1998).

The mapped distribution of surficial map units and the Dry Union Formation is based on field mapping and on interpretation of: (1) light detection and ranging (lidar) imagery generated from lidar data acquired during September 2010 that covers about 88 percent of the Granite $7.5^{\prime}$ quadrangle (see fig. 1); (2) 10-foot contour map generated from the lidar data; (3) National Agriculture Imagery Program (NAIP), http://www.fsa.usda.gov/FSA/apfoapp? area $=$ home\&subject $=p$ rog\&topic $=n a i)$ aerial imagery taken in 2011 for about 12 percent the of the Granite quadrangle not covered by lidar data (fig. 1), (4) 1:28,000-scale, NAIP natural color aerial photographs taken in September 2004 (http://www.fsa.usda. gov); and (5) 1:40,000-scale, black-and-white aerial photographs taken in September and October 1999 (National Aerial Photography Program, NAPP, http://www.usgs.gov/science/ cite-view.php? cite=553).

Typical particle sizes of surficial deposits and sediments of the Dry Union Formation in map-unit descriptions are

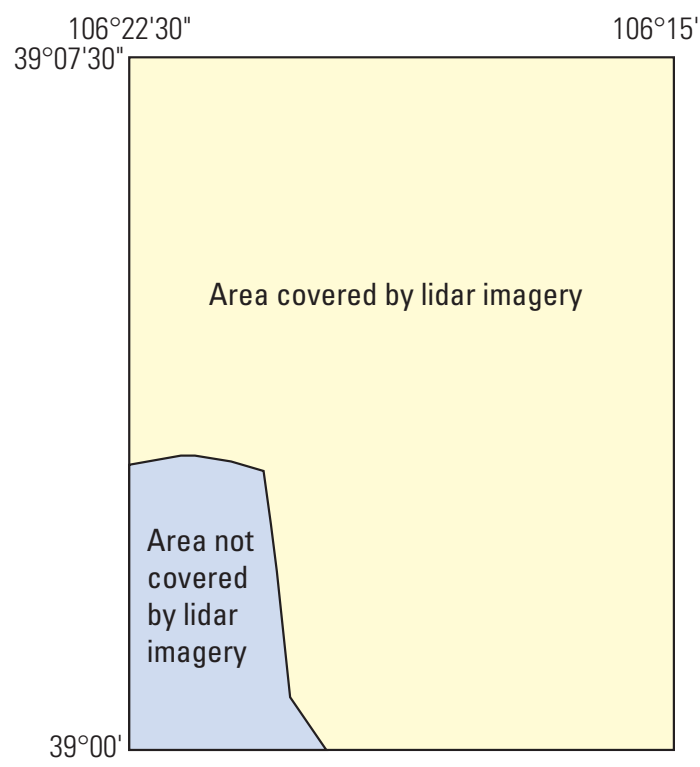

Figure 1. Area of Granite 7.5' quadrangle covered by light detection and ranging (lidar) imagery shown in yellow. This imagery, along with field observations, was used to map surficial deposits, Dry Union Formation, inferred faults, lineaments, fluvial scarps, and other geomorphic features. Area in blue indicates region of quadrangle not covered by lidar imagery data that was interpreted with the aid of National Agriculture Imagery Program (NAIP) imagery. field estimates. Size limits for sand $(2-0.05 \mathrm{~mm})$, silt $(0.05-$ $0.002 \mathrm{~mm})$, and clay $(<0.002 \mathrm{~mm})$ in table 1 are those of the Soil Survey Staff (1951). In descriptions of surficial deposits and the Dry Union Formation, the term "clasts" refers to granules and larger particles ( $>2 \mathrm{~mm}$ in diameter), whereas the term "matrix" refers to sand and finer particles $(\leq 2 \mathrm{~mm}$ in diameter). In descriptions of clast composition of surficial deposits and the Dry Union Formation, the terms "granitic" refer chiefly to rocks ranging in composition from granite to granodiorite, the term "gneiss" refers chiefly to biotite gneiss and hornblende gneiss. In this report, the terms "stream alluvium" and "fluvial deposits" refer to sediment transported by running water confined to channels, whereas the terms "sheetwash alluvium" and "sheetflood alluvium" refer to sediment transported by running water not confined to channels. The terms "colluvium" and "mass-movement deposits" refers to all rock and sediment transported downslope chiefly by gravity (Hilgard, 1892; Merrill, 1897). Material on slopes is transported chiefly by mass-movement (gravity-driven) processes - such as creep, debris flow, sliding, and rockfall - that are locally aided by running water not confined to channels.

Map units that include debris-flow deposits, such as some of the surficial map units and the Dry Union Formation, probably also include hyperconcentrated-flow deposits. These latter deposits have bedding and sorting characteristics intermediate between those of stream-flow and debris-flow deposits (Pierson and Costa, 1987; Meyer and Wells, 1997).

In this report, the terms "soil(s)" refer to pedogenic soils formed in surficial deposits and possibly in sediments of the Dry Union Formation. Soil-horizon designations are those of the Soil Survey Staff (1999), Birkeland (1999), and Schoeneberger and others (2012). Colors of surficial deposits and sediments of the Dry Union Formation, followed by numbers and letters (for example, 10YR 7/2), are for air-dried samples of the matrix and were determined with the aid of Munsell soil color charts (Munsell Color, 1973). All other colors for sediments and bedrock in this report are field designations.

The approximate height above stream level of the top of gravelly stream alluvium of middle Pleistocene to Holocene age was determined with the aid of a 1:14,000-scale topographic map with 10-foot contour intervals, which was generated from lidar data. Height above stream level referred to in this report is the difference in altitude (expressed in meters) between stream level and the down-slope limit of gravelly stream alluvium at or near its depositional top.

In this report, the term "sericitized" refers to plagioclase that has been altered to the mineral sericite. The term "migmatite" refers to biotite gneiss containing numerous layers and irregular pods of light-gray or white granitic rock (leucosomes), typically $0.1-10 \mathrm{~cm}$ thick but locally thicker, which in some places are strongly folded along with the enclosing biotite gneiss. Formation of leucosomes is generally attributed to partial melting of the biotite gneiss during metamorphism (Johannes and Gupta, 1982; Olsen, 1982; Cole and Braddock, 2009). 
Table 1. Particle-size analyses of loess and till in and near the Granite 7.5' quadrangle. Field-sample numbers and values from Shroba (1977). [Sample locations are not shown on the geologic map and are not in the geologic database. Samples were treated with sodium peroxide $\left(\mathrm{Na}_{2} \mathrm{O}_{2}\right)$ to remove organic matter and with dilute hydrochloric acid $(\mathrm{HCl})$ to remove any carbonate. Sodium hexametaphosphate $\left(\mathrm{NaPO}_{3}\right)_{6}$ was then added as a dispersant to all samples, which were subjected to ultrasonic vibration for 15 minutes. Particle-size analyses were performed by sieve-and-pipette methods (Shroba, 1977). Values are fraction of total weight (percent).]

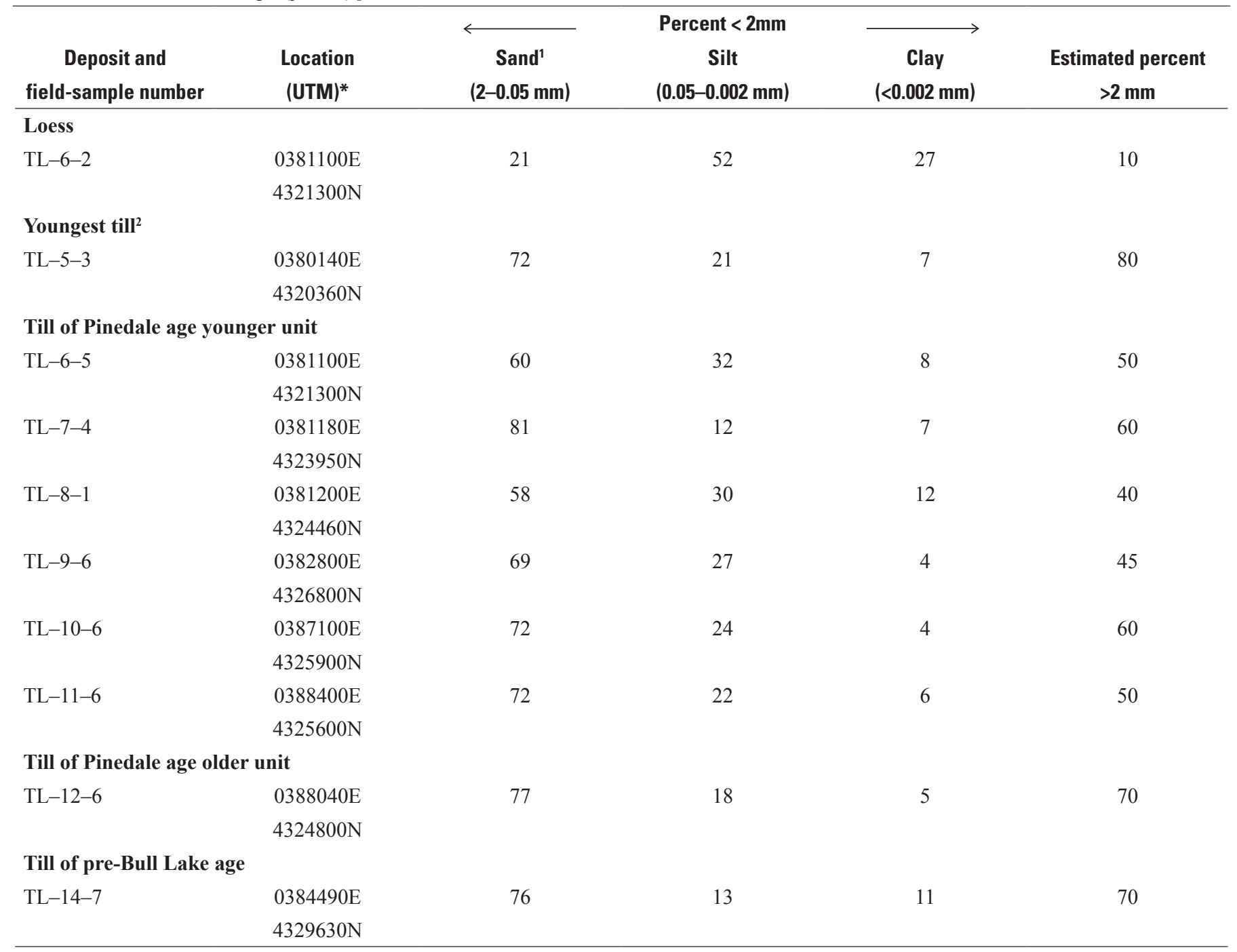

\footnotetext{
${ }^{1}$ Size ranges are those of the Soil Survey Staff (1951).

${ }^{2}$ Youngest till in Boswell Gulch may be equivalent to deposits of the Satanta Peak advance of Benedict $(1973 b, 1985)$ in the Indian Peaks area of the Front Range.
}

*Datum: North America 1927 


\title{
DESCRIPTION OF MAP UNITS
}

\author{
Surficial Deposits
}

Manmade Deposits

af

pt

$\mathrm{mt}$

$\mathrm{Qb}$

Qva

Artificial-fill deposits (latest Holocene) —Engineered, compacted fill material composed of rock fragments and finer material was emplaced in the Twin Lakes and Mount Elbert Forebay earth-fill dams, above the penstocks connecting Mount Elbert Forebay and the Mount Elbert power plant, beneath parts of U.S. Highway 24 and Colorado Highway 82, and railroad tracks on the east side of the Arkansas River. Unit also locally includes small un-compacted deposits composed of rock fragments and finer material. Estimated thickness is $3-30 \mathrm{~m}$

Placer-tailings deposits (latest Holocene) - Sandy, locally slightly bouldery, cobble gravel deposited by flowing water and power equipment. Unit also locally includes linear and irregularly shaped piles, as much as $3 \mathrm{~m}$ high, composed chiefly of cobbles and small boulders that appear to have been stacked by hand. These tailings piles locally contain boulders as large as $75 \times 120 \times 180 \mathrm{~cm}$. Deposits of unit pt were first produced (about $1860-1883$ ) by hand methods and ground sluicing and later (about 1884-1950) by hydraulic mining, dredging, and dragline in order to concentrate native gold (Parker, 1974a, 1974b). Placer-tailings deposits and gold were derived chiefly from cobbly glacial outwash (Qopy and Qoey) and fluvial gravel in the Dry Union Formation (Nd). Small tailings deposits between Cache Creek and Lake Creek were derived from deposits of alluvium and colluvium, undivided (Qac), colluvium (Qc), and fan deposits (Qf). A considerable amount of sand and finer sediment, transported by water flowing from areas of hydraulic mining along and near Cache Creek, was conveyed to the Arkansas River by a network of wooden flumes. From south to north, the most extensive placer-tailings deposits in the map area are along and near Cache Creek, Lake Creek, and Corske Creek. Estimated thickness is $1-10 \mathrm{~m}$

Mine-tailings deposits (latest Holocene) - Four piles of un-compacted, very angular rock debris dumped near small abandoned mines. Two in Sheephead Gulch and Boswell Gulch near the southwest corner of the map area, and two near Twobit Gulch and Spring Creek east of the Arkansas River. Rock fragments in deposits of unit mt commonly range in size from about $50 \mathrm{~cm}$ in diameter to sand-sized particles. These deposits were produced during the exploration and (or) the extraction of gold-bearing ore, and locally silver-bearing ore, between the early 1860s and as late as the 1930s (Hedlund and others, 1983; Gese and Scott, 1993; Cappa and Bartos, 2007). Estimated thickness is 1-10 m

\section{Lacustrine Deposits}

Beach deposits (latest Holocene) - Mostly deposits of coarse sand, pebbly coarse sand, and pebble gravel. Deposits of unit $\mathrm{Qb}$ were formed, after the construction of the Twin Lakes dam in 1978, by wave action on outwash deposits of Pinedale age younger unit (Qopy) at two areas along the northern and eastern shores of the Twin Lakes Reservoir near an altitude of 2,805 m. Unit locally may include a minor amount of outwash of Pinedale age younger unit. Estimated thickness is 1-2 m; possibly thicker near the Twin Lakes dam (Tweto, 1978)

\section{Alluvial Deposits}

Valley-floor alluvium (Holocene and latest Pleistocene?) - Chiefly poorly sorted pebbly sand and pebbly to cobbly gravel in stream channels and floodplains and beneath low terraces (1-2 $\mathrm{m}$ high) along the Arkansas River and its major eastward flowing tributaries (table 2). Gravelly alluvium in floodplains is commonly overlain by about $30 \mathrm{~cm}$ or more of overbank sediment composed of slightly pebbly, very fine to very coarse sand that contains a minor amount of granules. Unit Qva locally includes bouldery deposits along tributary streams near the northern boundary of the map area, and small deposits of sheetwash alluvium (Qsw), small fan deposits (Qf), and colluvium (Qc) along valley margins. Unit Qva locally may 
include deposits of outwash of Pinedale age younger unit (Qopy). In glaciated valleys and in the valley of the Arkansas River, unit Qva probably overlies outwash of Pinedale age younger unit (Qopy). The long, low north-south trending fluvial scarp near the northern boundary of the map area corresponds with the western boundary of young anastomosing stream-channel and thin overbank sediments deposited by the Arkansas River. Deposits of unit Qva are a potential source of clean coarse aggregate. However, hydrologic factors such as locally high-water tables and periodic flooding, as well as geologic factors such as thickness of fine-grained overbank sediments and the amount of large cobbles and boulders, may render these deposits less suitable than some of the deposits of outwash gravel within the map area. Low-lying deposits are prone to periodic flooding. Estimated thickness is 5-10 m

Qsw

Qsw/Nd

Qopy

Qopo
Sheetwash alluvium (Holocene and late Pleistocene) - Few small deposits commonly composed of slightly pebbly to pebbly, slightly silty, fine to very coarse sand and a minor amount of granules deposited by overland flow on gentle slopes along and near the Arkansas River. Much of the unit is probably derived from erosion of sandy layers in the Dry Union Formation (Nd) and grus formed chiefly by chemical weathering and disintegration of the granite of Granite (Ygrg). Charcoal fragments collected from the base of a thin $(29 \mathrm{~cm})$ deposit of sheetwash alluvium that overlies outwash gravel of pre-Bull Lake age about $2 \mathrm{~km}$ north of the map area yielded a radiocarbon age of about $4.0 \mathrm{ka}$ (Nelson and Shroba, 1998). Thin deposits of sheetwash alluvium, too narrow to map separately, locally overlie outwash deposits at and near valley sides. Low-lying areas of unit Qsw are susceptible to sheet flooding due to unconfined overland flow, and locally may be susceptible to gullying. Estimated thickness is $1-7 \mathrm{~m}$

\section{Sheetwash alluvium over Dry Union Formation}

Outwash of Pinedale age (late Pleistocene) - Glaciofluvial deposits composed chiefly of clast-supported, poorly sorted, and crudely stratified coarse cobbly pebble gravel deposited by meltwater streams during the Pinedale glaciation. Units (Qopy and Qopo) locally include layers and lenses of sandy pebble gravel and pebbly sand. Gravelly deposits are locally overlain by about $30-50 \mathrm{~cm}$ of overbank sediment composed of pebbly sand (Nelson and Shroba, 1998). Deposits proximal to till of Pinedale age (Qtpy and Qtpo) are bouldery and locally contain boulders as large as $110 \times 140 \times 180 \mathrm{~cm}$. Soils formed in outwash of Pinedale age have cambic B (Bw) or weakly developed argillic B (Btj and Bt) horizons about $30 \mathrm{~cm}$ thick (Nelson and Shroba, 1998). The exposed portions of most surface boulders of granitic composition show little evidence of weathering. Outwash deposits of Pinedale age are a potential source of clean coarse aggregate, although locally they contain a significant amount of large cobbles and boulders and some of the biotite-rich pebbles and small cobbles are partly or completely disintegrated, probably due to chemical weathering and expansion of biotite (Wahrhaftig, 1965; Isherwood and Street, 1976)

Younger unit-Unit underlies terraces and terrace remnants about 2-3 $\mathrm{m}$ above Clear Creek, Cache Creek, and Corske Creek, 2-7 m above Lake Creek, and 2-12 m above the Arkansas River (table 2). Unit along Lake Creek near Balltown locally contains boulders as large as about $270 \times 300 \times 300 \mathrm{~cm}$. These boulders probably were deposited by one or more glacial-outburst floods (jökulhlaups) initiated by the rapid drainage of a lake or lakes impounded by glacial ice or moraines of unit Qtpy in the vicinity of the Twin Lakes dam. Unit Qopy includes one small kame deposit composed chiefly of sandy pebble gravel, about $0.7 \mathrm{~km}$ southwest of the Mt. Elbert power plant. About $0.5 \mathrm{~km}$ southeast of Balltown (fig. 2), unit Qopy locally includes placer-tailings deposits (pt) that are too small to show at map scale. In the valleys of Lake Creek and Clear Creek, deposits of unit Qopy are graded to and coeval with till of unit Qtpy, which dates from about 22-15 ka (D.P. Dethier, Williams College, Williamstown, Mass., written commun., 2010; Young and others, 2011). Estimated thickness is 3-20 m; possibly $50 \mathrm{~m}$ or more on the up-valley sides of terminal moraines in the valleys of Lake Creek and Clear Creek

Older unit-Unit underlies terrace remnants about $18 \mathrm{~m}$ above Lake Creek and 18-24 m above the Arkansas River (table 2). On the east side of the Arkansas River, the top part of the unit locally contains many very angular rockfall-derived boulders as large as $140 \times 160 \times 290$ 
$\mathrm{cm}$. The top part of the unit at the eastern boundary of the map area southeast of the town of Granite contains boulders as large as $140 \times 255 \times 520 \mathrm{~cm}$, and may be a glacial-outburst flood deposit. Near the confluence of Lake Creek with the Arkansas River, deposits of unit Qopo are graded to and coeval with till of unit Qtpo, which is older than $20 \mathrm{ka}$ in the valley of Lake Creek (D.P. Dethier, Williams College, Williamstown, Mass., written commun., 2010) and older than $22 \mathrm{ka}$ in the valley of Clear Creek (Young and others, 2011). Estimated thickness is $3-20 \mathrm{~m}$

Outwash of Bull Lake age (late and middle Pleistocene) - Glaciofluvial deposits composed chiefly of coarse cobbly pebble gravel deposited by meltwater streams during the Bull Lake glaciation. Units (Qoby and Qobo) locally include layers and lenses of sandy pebble gravel and pebbly sand. Gravelly deposits are locally overlain by about 20-30 cm of overbank sediment composed of pebbly sand (Nelson and Shroba, 1998). Deposits proximal to till of Bull Lake age (Qtb) are bouldery and locally contain boulders as large as $120 \times 130 \times 260 \mathrm{~cm}$. Soils formed in outwash of Bull Lake age have argillic B (Bt) horizons commonly about 40-65 cm thick (Nelson and Shroba, 1998). The exposed portions of some surface boulders of granitic composition are extensively weathered. Some of these boulders are "hat shaped" and have "brims" about 15-60 cm wide. Outwash deposits of Bull Lake age are a potential source of coarse aggregate, although locally they contain a significant amount of large cobbles and boulders and many of the biotite-rich pebbles and cobbles are partly or completely disintegrated

Qoby Younger unit (late and middle Pleistocene)-Unit underlies terrace remnants about $37 \mathrm{~m}$ above the Arkansas River (table 2). On the south side of Lake Creek, deposits of unit Qoby are graded to and coeval with till of unit Qtb. On the north side of Lake Creek, at the confluence of Lake Creek and the Arkansas River, the top of unit Qoby locally is overlain by scattered boulders of granitic composition that are commonly 1-2 $\mathrm{m}$ long. The largest boulder is $>100 \times 210 \times 400 \mathrm{~cm}$. These boulders probably were deposited by one or more glacial-outburst floods initiated by the rapid drainage of a lake or lakes impounded by glacial ice or moraines of unit Qtb farther upstream in the Lake Creek drainage. Estimated thickness is $3-20 \mathrm{~m}$

Qobo Older unit (middle Pleistocene)-Unit underlies terrace remnants about $43 \mathrm{~m}$ above the Arkansas River (table 2). On the south side of Lake Creek, deposits of unit Qobo are graded to and coeval with till of unit Qtb. Estimated thickness is 3-20 m

Outwash of pre-Bull Lake age (middle Pleistocene) - Glaciofluvial deposits composed chiefly of coarse cobbly pebble gravel deposited by meltwater streams probably during two or more pre-Bull Lake glaciations, and one deposit of pebble gravel of non-glacial origin. Units (Qoey and Qoeo) locally include layers and lenses of sandy pebble gravel and pebbly sand. Gravelly deposits are locally overlain by about $20-30 \mathrm{~cm}$ of slightly pebbly, slightly silty sand. These thin layers may be overbank sediment or loess (windblown silt) mixed with underlying alluvium (Nelson and Shroba, 1998). Deposits proximal to till of pre-Bull Lake age (Qte) are bouldery and locally contain boulders as large as $>80 \times 190 \times 235 \mathrm{~cm}$. Soils formed in outwash of pre-Bull Lake age have clayey argillic $\mathrm{B}(\mathrm{Bt})$ horizons that are $30 \mathrm{~cm}$ to greater than $120 \mathrm{~cm}$ thick and carbonate-enriched calcic horizons (Bk and $\mathrm{Btk}$ ) horizons $45 \mathrm{~cm}$ to greater than $60 \mathrm{~cm}$ thick with stage I to strong stage II carbonate morphology (Alan R. Nelson, Bureau of Reclamation, Denver, Colo., written commun., 1981). The exposed portions of surface boulders of granitic composition are extensively weathered. Some of these boulders are "hat shaped" and have "brims" about 50-160 cm wide. Outwash deposits of pre-Bull Lake age are a potential source of coarse aggregate, although locally they contain a significant amount of large cobbles and boulders and all of the biotite-rich pebbles and cobbles are partly or completely disintegrated

Qoey Younger unit-Unit underlies terrace remnants at three levels about 55-61, 67-72, and $79-87 \mathrm{~m}$ above the Arkansas River (table 2). Unit also includes a deposit of pebble gravel rich in granitic clasts on the north side of Sawmill Gulch, about $80 \mathrm{~m}$ above the Arkansas River, near the northern boundary of the map area. About $1 \mathrm{~km}$ northwest of the Granite Cemetery, the uppermost deposits of unit Qoey includes a S. 50 ${ }^{\circ}$ E.-trending flood- 
deposited gravel body about $40 \mathrm{~m}$ long and $20 \mathrm{~m}$ wide that contains widely spaced boulders. Most of the boulders are granitic in composition and are commonly 40-120 cm long. Boulders on unit Qoey transported by the Arkansas River are commonly about $30-40 \mathrm{~cm}$ in length and are locally as large as $70 \times 75 \times 120 \mathrm{~cm}$. West of the river boulders transported by tributary streams are slightly larger. Commonly, they are about $30-60 \mathrm{~cm}$ in length and are locally as large as $\geq 85 \times 120 \times 200 \mathrm{~cm}$. On the north side of Clear Creek, the highest deposits of unit Qoey appear to be graded to and may be coeval with till of unit Qte. Estimated thickness is $1.5-15 \mathrm{~m}$ for deposits east of the Arkansas River and 10-20 m for deposits west of the Arkansas River

Qoeo

Older unit - Unit underlies a high terrace north of Lake Creek and includes two small gravel deposits east of the Arkansas River. The tops of the terrace and the gravel deposits are about 95-110 m above the Arkansas River (table 2). Clast composition indicates that eastward flowing streams tributary to the Arkansas River as well as the southeast-flowing Arkansas River deposited the glaciofluvial gravel beneath the large northwest-southeast-trending terrace; whereas, the two small gravel deposits east of the Arkansas River were deposited by the Arkansas River. The uppermost deposits of unit Qoeo at the south end of the high terrace, just north of Lake Creek, include two parallel S. $50^{\circ}$ E. trending flood-deposited gravel bodies about $80 \mathrm{~m}$ long and $20 \mathrm{~m}$ wide that contain many large boulders. These boulders are granitic in composition and are commonly 140-240 cm long. The largest boulder is $\geq 180 \times 200 \times 420 \mathrm{~cm}$. These boulders probably were deposited by one or more glacial-outburst floods, which may have originated in the Lake Creek drainage. Deposits of unit Qoeo on the north side of Lake Creek are graded to and coeval with till of unit Qte. Unit Qoeo may be correlative with outwash gravel $4 \mathrm{~km}$ southwest of Nathrop, Colo. (Nelson and Shroba, 1998, p. 354, fig. 3). The gravel near Nathrop is about $100 \mathrm{~m}$ above the Arkansas River and is overlain by fine-grained sediment that contains Lava Creek B ash (Scott and others, 1975; Izett and Wilcox, 1982), which is about $640 \mathrm{ka}$ (Lanphere and others, 2002). Unit Qoeo is likely to be younger than the next older outwash gravel located $7 \mathrm{~km}$ southwest of Nathrop. This older gravel is about $165 \mathrm{~m}$ above the Arkansas River and is overlain by fine-grained sediment that contains the Bishop ash (Scott and others, 1975; Izett and others, 1988), which is about $760 \mathrm{ka}$ (Sarna-Wojcicki and others, 2000). Estimated thickness is $2-5 \mathrm{~m}$ for the deposits east of the Arkansas River and 10-20 m for the deposit west of the Arkansas River

\section{Alluvial and Mass-movement Deposits}

Qac Alluvium and colluvium, undivided (Holocene to middle? Pleistocene) - Composed chiefly of undifferentiated sandy and gravelly stream alluvium, sheetwash alluvium (Qsw), fan deposits (Qf), colluvium (Qc), and locally other mass-movement deposits along minor streams and on adjacent lower (toe) slopes. Along Cache Creek, the top 50-100 cm of unit Qac consists of brownish-black, humic overbank sediments composed of slightly pebbly and locally granule-rich silty sand. Sediments at the mouth of Bartlett Gulch, near the western boundary of the map area, probably include deposits of humic silty sand. Unit Qac along Cache Creek and near the head of Lost Canyon, about $5 \mathrm{~km}$ south of the Twin Lakes Reservoir, locally contains small placer-tailings deposits (pt). Low-lying areas of unit Qac adjacent to stream channels may be subject to periodic stream flooding and debrisflow deposition. The adjacent toe slopes may be susceptible to local sheet flooding due to unconfined overland flow, and locally to gullying. Estimated thickness is $3-15 \mathrm{~m}$

Fan deposits (Holocene to middle? Pleistocene) - Mostly poorly sorted, clast-supported, slightly bouldery pebble and cobble gravel and locally minor deposits composed of matrix-supported, pebbly and cobbly silty sand. Clasts are commonly very angular to subangular. Boulders are locally $1-2 \mathrm{~m}$ long. Deposited chiefly by streams and debris flows in fan- and tongue-shaped accumulations near base of moderate to steep slopes of the Sawatch Range and locally along the steep flanks of lateral moraines of unit Qtpy in the valleys of Lake Creek and Clear Creek. Snails (cf. Catinella) from a fan deposit along the north shore of Clear Creek Reservoir (NW1/4 of sec. 7, T. 12 N., R. 79 W.) had amino 
acid ratios that suggest a pre-Holocene age for some beds within the fan (A.R. Nelson, U.S. Geological Survey (USGS), written commun., 2013). Unit probably locally includes deposits of sheetwash alluvium (Qsw), colluvium (Qc), and probably hyperconcentratedflow deposits. Low-lying areas on the unit may be subject to periodic stream flooding and debris-flow deposition. Estimated thickness is $1-15 \mathrm{~m}$

\section{Mass-movement Deposits}

Qta

Qc

$\mathrm{Qc} / \mathrm{Nd}$

Qls

Talus deposits (Holocene to middle? Pleistocene) - Very angular and angular boulders as much as $5 \mathrm{~m}$ long and smaller rock fragments deposited chiefly by rock and snow avalanche, rockfall, rock slide, and debris flow at the base of cliffs and steep slopes where debris forms broad aprons, small cones, and fan-shaped deposits. Unit locally includes rubbly scree deposits and small debris-flow deposits. Unit Qta near the head of Boswell Gulch, near southwest corner of the map area, locally overlies rock-glacier deposits (Qrg) and till of Pinedale age younger unit (Qtpy). A thin $(10 \mathrm{~cm})$ layer, that may be loess mixed with or infiltrated into the underlying debris, locally overlies unit Qta near the head of Boswell Gulch. Talus deposits in the valley of Clear Creek, which extend below the up-slope limit of the glacial ice extent during the Pinedale glaciation, postdate the retreat of Pinedale ice. Deposits derived from steep Proterozoic bedrock outcrops along the Arkansas River, too small to show at map scale, locally overlie deposits of unit Qopo. Estimated thickness is $1-15 \mathrm{~m}$

Colluvium (Holocene to middle? Pleistocene) - Non-sorted, mostly matrix-supported deposits that consist of clay-, silt-, and sand-sized particles, and clasts that range in size from granules to large boulders. Deposits of unit Qc are formed by a variety of massmovement processes. Unit includes deposits on sagebrush-covered and forested slopes as well as deposits in the large alpine area, at and above present day treeline (about 3,4803,690 m) near the head of Lost Canyon, where freeze-thaw action has promoted massmovement and downslope transport. The composition of the deposits reflects that of the underlying or nearby bedrock or sediments from which the colluvium was derived. In areas of Proterozoic bedrock, unit Qc probably consists chiefly of transported grus and corestones. Unit Qc locally includes material transported by frost creep, solifluction, nivation, periglacial processes, sheetwash, sliding, debris flow, hyperconcentrated flow, earth flow, and rockfall, and by minor ephemeral steams. In the large alpine area near the head of Lost Canyon, unit Qc locally includes solifluction deposits that form large stair-steps with broad treads and low risers that are roughly parallel to the contours. These deposits are probably similar in origin to the turf-bank terrace deposits (Benedict, 1970) in the Indian Peaks region of the Front Range, about $120 \mathrm{~km}$ northeast of the map area. Unit Qc locally includes small bodies of Proterozoic bedrock too small to show at map scale. Estimated thickness is 3-15 m

\section{Colluvium over Dry Union Formation}

Landslide deposits (Holocene to middle? Pleistocene) - Deposits composed of unsorted and unstratified debris of various sizes commonly at or near the base of moderate to steep slopes. These deposits commonly have hummocky topography. The largest landslides and landslide deposits form on unstable slopes that are underlain by sediments of Dry Union Formation $(\mathrm{Nd})$ near the northern and western boundary of the map area and on highly fractured Proterozoic bedrock (Ygrg) near the southwest corner of the map area. Younger landslide deposits are commonly bounded upslope by crescent-shaped headwall scarps and downslope by lobate toes. Older landslide deposits commonly lack scarps and have more muted surface morphology. Unit Qls includes material displaced chiefly by rotational debris slides, translational rock and debris slides, debris flows, and possibly minor earth flows as defined by Varnes and Cruden (1996). The sizes and lithologies of the clasts and the particle-size distributions of the matrices of these deposits reflect those of the displaced bedrock units and surficial deposits. The large landslide deposits on the north side of Cache Creek, on the north side of the Twin Lakes Reservoir, at the northwest corner of the map area, and on the west side of the Arkansas River near the northern boundary of the 
map area are derived chiefly from sediments of unit $\mathrm{Nd}$. Locally, these landslide deposits contained small intact blocks and deformed lens-shaped bodies of unit $\mathrm{Nd}$. Unit Qls locally includes small deposits of sheetwash alluvium (Qsw) and marsh or bog deposits that accumulated in unfilled depressions. The large landslide deposit derived from Proterozoic bedrock north of Clear Creek near the southwest corner of the map area locally has prominent up-slope facing scarps, referred to as sackungen (Varnes and others, 1989; McCalpin and Irvine, 1995). Small talus deposits (Qta), too small to show at map scale, locally mantle the large bedrock-derived landslide deposit at the southern boundary of the map area. The landslide deposits along the north and south shores of Twin Lakes Reservoir, along the valley of Clear Creek, and near the northwest corner of the map area formed after melting and retreat of the Pinedale glaciers in these areas. Some of these latter landslide failures of unconsolidated or weakly consolidated sediments on steep slopes may have been due in part to steep slopes, high water content, and high pore-water pressures in unstable sediments as well as the removal of lateral support formerly provided by glacial ice prior to melting. Landslide deposits may be prone to continued movement or reactivation due to both natural and human-induced processes. Estimated thickness is $5-45 \mathrm{~m}$

\section{Glacial Deposits}

Rock-glacier deposits (early Holocene? and latest Pleistocene?) —-Large masses composed of boulder- to-silt-sized rock debris that have relatively steep fronts and flanks, and gently sloping upper surfaces. Deposits of unit Qrg mantle lobate (width greater than length) rock glaciers, as defined by Wahrhaftig and Cox (1959). They formed at or near the base of talus deposits (Qta) at an elevation of 3,500-3,710 $\mathrm{m}$ in the cirque at the head of Boswell Gulch, near the southwest corner of the map area. Deposits of unit Qrg probably consist of a veneer of angular boulder- and cobble-sized clasts that overlies smaller debris. Rock fragments on and within unit Qrg probably accumulated chiefly by rockfall and locally by sliding, and snow and rock avalanche. These fragments are probably moved downslope by creep or flowage. The upper surfaces of the unit locally have prominent longitudinal and transverse ridges and furrows, and a few collapse pits. The lower part of the unit may be ice-cemented debris or may have an ice core. Lobate rock glaciers commonly are icecemented (Benedict, 1973a; White, 1976), and likely formed under periglacial conditions (Barsch, 1987). Unit Qrg overlies till of Pinedale age younger unit (Qtpy), and locally may include minor debris-flow deposits and talus deposits (Qta) displaced by creep. A thin $(5-10 \mathrm{~cm})$ loess mantle locally overlies rock-glacier deposits in La Plata Basin (Shroba, 1977), about $8 \mathrm{~km}$ west of the map area. Many of the rock-glacier deposits in Colorado are considered to be of latest Pleistocene or early Holocene age (Meierding and Birkeland, 1980). Estimated maximum thickness is $45 \mathrm{~m}$

Till of Pinedale age (late Pleistocene) - Mostly non-sorted and non-stratified, subangular and subrounded boulders to granules in a matrix composed of very slightly clayey, slightly silty sand (table 1). Deposits locally may contain significant amounts of silt, sand, or gravel in areas where glaciers have eroded pro-glacial lacustrine sediments, outwash, or sediments of the Dry Union Formation (Nd). Material $>2 \mathrm{~mm}$ in diameter is estimated to be $40-70$ percent of the unit. Some of the surface boulders of granitic composition are as large as $\geq 450$ $\times 550 \times 700 \mathrm{~cm}$. Units (Qtpy and Qtpo) locally include small bodies of silt, sand, and gravel deposited by meltwater, and are locally overlain by till-derived landslide deposits (QIs). Soils formed in till of Pinedale age have thin $(7-22 \mathrm{~cm})$ cambic $\mathrm{B}(\mathrm{Bw})$ horizons, or they lack B horizons and have A/Cox or A/Bk profiles (Shroba, 1977; Nelson and Shroba, 1998). Calcic (Bk) horizons have weak stage I carbonate morphology. Depth of oxidation (base of Cox horizon) ranges from about 50 to $170 \mathrm{~cm}$. Unoxidized till is gray (commonly 10YR 7/2, 2.5Y 7/2, and 5Y 7/2), whereas soil B horizons are light brown (7.5 YR 5/3). Locally, as much as 15 percent of the biotite-rich pebbles and small cobbles within soils are partly or completely disintegrated (Shroba, 1977). The exposed portions of some of the surface boulders of granitic composition are weathered. Probably less than 1 percent of these weathered boulders are "hat shaped" and have "brims" about 10-25 cm wide. Surface boulders typically are more abundant on moraines of the Pinedale glaciation than on those 
of older glaciations. Deposits form bouldery, prominent, sharp-crested lateral moraines along Clear Creek as well as lateral and end moraines with similar surface morphology along Lake Creek and in Boswell Gulch. Moraines locally have unfilled and undrained depressions. Pinedale glaciers were as thick as $350 \mathrm{~m}$ in the valley of Lake Creek and flowed $31 \mathrm{~km}$ down valley from an altitude of about 3,900 $\mathrm{m}$ to an altitude of about 2,780 $\mathrm{m}$. In the valley of Clear Creek, glaciers were as thick as $400 \mathrm{~m}$ and flowed

$23 \mathrm{~km}$ down valley from an altitude of about 3,800 $\mathrm{m}$ to an altitude of about 2,680 $\mathrm{m}$. Estimated thickness is $1.5-45 \mathrm{~m}$

Qtpy

Younger unit-In the valleys of Lake Creek and Clear Creek, till of unit Qtpy is graded to and coeval with outwash deposits of unit Qopy. Six ${ }^{10} \mathrm{Be}$ surface-exposure ages of boulders on moraines within the map area indicate that till of unit Qtpy in the valleys of Lake Creek and Clear Creek dates from about 22-15 ka (D.P. Dethier, Williams College, Williamstown, Mass., written commun., 2010; Young and others, 2011). These ages are compatible with five ${ }^{10} \mathrm{Be}$ surface-exposure ages (21-16 ka) reported by Brugger (2007) for boulders on deposits that form the outermost moraines of the last glacial maximum in the Taylor River drainage, about $20 \mathrm{~km}$ southwest of the map area. There are $s i{ }^{10} \mathrm{Be}$ surface-exposure ages of glacially scoured bedrock surfaces. Three are located in the valley of Lake Creek about 3,8, and $17 \mathrm{~km}$ west of the map area, one in the valley of Clear Creek near the southern boundary of the map area, and two ${ }^{10} \mathrm{Be}$ surface-exposure ages within a cirque about $12 \mathrm{~km}$ northwest of the map area. These ages suggest that much or all of unit Qtpy in Boswell Gulch dates from about 15-13 ka (Mason and others, 2011; Young and others, 2011; Ruleman and others, 2013). Unit Qtpy in Boswell Gulch is down valley of and older than bouldery till that forms a small sharp-crested moraine at an altitude of 3,780 $\mathrm{m}$ at the head of Boswell Gulch, about $0.7 \mathrm{~km}$ west of the map area. This till is the youngest till observed in the cirques in and near the map area (sample TL-5-3, table 1). It may be correlative with deposits of the Satanta Peak advance of Benedict (1973b, 1985) in the Indian Peaks region of the Front Range, about $120 \mathrm{~km}$ northeast of the map area. Deposits of the Satanta Peak advance have minimum-limiting radiocarbon $\left({ }^{14} \mathrm{C}\right)$ ages of about 9.9 and $9.7 \mathrm{ka}$ (Benedict, 1973b). These deposits probably date from 12 to $10 \mathrm{ka}$ B.P. (Benedict, 1985), and may be coeval with glacial deposits formed during the Younger Dryas climatic event (about 11-10 ka) in northwestern North America and northern Europe (Menounos and Reasoner, 1997). A thin loess mantle, about $20 \mathrm{~cm}$ thick, locally overlies unit Qtpy near the head of Boswell Gulch (sample TL-6-2, table 1). Loess was not observed elsewhere on unit Qtpy or on any of the other till units within the map area

Older unit—Near the confluence of Lake Creek with the Arkansas River, the till of unit Qtpo is graded to and coeval with outwash deposits of unit Qopo. The oldest of five ${ }^{10} \mathrm{Be}$ surface-exposure ages for boulders on the outer lateral moraines of unit Qtpy on the north side of Clear Creek Reservoir suggest that nearby deposits of unit Qtpo are older than $22 \mathrm{ka}$ (Young and others, 2011). Unit Qtpo may be about $30 \mathrm{ka}$ (Nelson and others, 1979). It may be correlative with an early advance of Pinedale ice about 47-34 ka in the northern Yellowstone area (Sturchio and others, 1994) or with an earliest Pinedale advance at about 70-50 ka at McCall, Idaho, and in the Wind River Range near Lander, Wyo. (Dahms, 2004; Pierce and others, 2011)

Till of Bull Lake age (late and middle Pleistocene) - Mostly non-sorted and non-stratified, subangular and subrounded boulders to granules in a matrix composed of very slightly clayey, slightly silty sand. Deposits locally may contain significant amounts of silt, sand, or gravel in areas where glaciers have eroded proglacial lacustrine sediments, outwash, or sediments of the Dry Union Formation (Nd). Material $>2 \mathrm{~mm}$ in diameter is estimated to be 40-70 percent of the unit. Some of the surface boulders of granitic composition are as large as $\geq 140 \times 350 \times 380 \mathrm{~cm}$. Unit locally includes small deposits of sheetwash alluvium (Qsw) and colluvium (Qc) on the lower flanks of moraines and probably locally includes small bodies of silt, sand, and gravel deposited by meltwater. Soils formed in till of Bull Lake age have argillic B (Bt) horizons about $45-50 \mathrm{~cm}$ thick. These horizons are about two to three times as thick and contain about twice as much clay compared to argillic B horizons formed in till of Pinedale age. Many of the biotite-rich pebbles and cobbles 
within soils formed in till of Bull Lake age are partly or completely disintegrated. The exposed portions of many of the surface boulders of granitic composition are extensively weathered. Some of these boulders are "hat shaped" and have "brims" about 20-130 cm wide. Surface boulders typically are less abundant and are more weathered on moraines of the Bull Lake glaciation than on those of the Pinedale glaciation. Deposits of unit Qtb form prominent lateral moraines that have rounded crests along and near the Twin Lakes Reservoir, Clear Creek Reservoir, and Dry Columbia Gulch, near the southeast corner of the map area. Undrained depressions are rare. K-Ar and ${ }^{230} \mathrm{Th} / \mathrm{U}$ analyses that constrain the ages of glaciofluvial deposits near the type area for deposits of the Bull Lake glaciation along the northern flank of the Wind River Range, Wyo., and ages of glacial deposits near West Yellowstone indicate that the Bull Lake glaciation probably began prior to $167 \pm 6.4 \mathrm{ka}$ (possibly $190 \mathrm{ka}$ ) and may have continued until about $122 \pm 10 \mathrm{ka}$ (Sharp and others, 2003; Pierce, 2004). ${ }^{10} \mathrm{Be}$ ages for the West Yellowstone glacial system yield a mean age of $136 \pm 13 \mathrm{ka}$ and oldest ages of about 151-157 ka (Licciardi and Pierce, 2008). ${ }^{10} \mathrm{Be}$ and ${ }^{26} \mathrm{Al}$ analyses of surface boulders on moraines composed of till of Bull Lake age near Nederland, Colo., about $110 \mathrm{~km}$ northeast of the map area, yielded minimum age estimates of $101 \pm 21$ and $122 \pm 26 \mathrm{ka}$ (Schildgen and others, 2002). These age estimates are in accord with a uranium-trend age estimate of $130 \pm 40$ ka for till of Bull Lake age (Shroba and others, 1983) near Allens Park, Colo., about $135 \mathrm{~km}$ northeast of the map area. On the south side of Lake Creek, till of unit Qtb is graded to and coeval with outwash deposits of units Qoby and Qobo. Glacial ice during the Bull Lake glaciation flowed $31 \mathrm{~km}$ down the Lake Creek valley to an altitude of about 2,800 m, and $21 \mathrm{~km}$ or more down the valley of Clear Creek to an altitude of about 2,780 m. Estimated thickness is $1.5-30 \mathrm{~m}$ gular and subrounded boulders to granules in a matrix composed of slightly clayey, slightly silty sand (sample TL-14-7, table 1). Deposits locally may contain significant amounts of silt, sand, or gravel in areas where glaciers have eroded pro-glacial lacustrine sediments, outwash, or sediments of the Dry Union Formation ( $\mathrm{Nd})$. Material $>2 \mathrm{~mm}$ in diameter is estimated to be 40-70 percent of the unit. Some of the surface boulders of granitic composition are as large as $\geq 125 \times \geq 190 \times 210 \mathrm{~cm}$. North of Lake Creek, unit locally includes till assigned to the Bull Lake glaciation by Nelson and Shroba (1998). Unit probably locally includes small deposits of sheetwash alluvium (Qsw) and colluvium (Qc) on the lower flanks of moraines as well as small bodies of silt, sand, and gravel deposited by meltwater. Soils formed in till of pre-Bull Lake age have clayey argillic B (Bt) horizons about $90 \mathrm{~cm}$ thick that contain about twice as much clay as those formed in till of Bull Lake age (Shroba, 1977; Nelson and Shroba, 1998). All of the biotite-rich pebbles and cobbles within soils are partly or completely disintegrated. The exposed portions of many of the surface boulders of granitic composition are extensively weathered. Some of these boulders are "hat shaped" and have "brims" about 95-105 cm wide. Surface boulders typically are much less abundant on till of pre-Bull Lake age than on those of younger glaciations. This difference in relative abundance is probably due in part to weathering of surface boulders and possibly to fewer boulders in till of pre-Bull Lake age. Deposits of unit Qte form subdued lateral and end moraines that have broad rounded crests on the north side of the Twin Lakes Reservoir; those on the north side of Clear Creek lack morainal morphology. Undrained depressions were not observed. Till of unit Qte on the north side of Lake Creek is graded to and coeval with outwash deposits of unit Qoeo, the top of which is 95-110 m above the Arkansas River. Till of unit Qte on the north side of Clear Creek appears to be graded to and may be coeval with the highest outwash deposits of unit Qoey, the top of which is 79-87 m above the Arkansas River. If deposits of unit Qoeo on the north side of Lake Creek are correlative with gravelly alluvium $98 \mathrm{~m}$ above the Arkansas River near Nathrop, Colo., which is overlain by Lava Creek B ash, then deposits of unit Qte on the north side of Lake Creek are correlative with till of the Sacagawea Ridge glaciation. Deposits of this glaciation are located on the northern flank of the Wind River Range, Wyo., where the uppermost part of outwash of the Sacagawea Ridge glaciation contains water-lain Lava Creek B tephra (Richmond, 1976; Izett and Wilcox, 1982; Richmond and Murphy, 1989). The stratigraphic position of this tephra layer suggests that the Sacagawea Ridge glaciation occurred during marine 
oxygen isotope stage 16 (Chadwick and others, 1997), about 675-621 ka (Lisiecki and Raymo, 2005). The height of the highest outwash gravel of unit Qoey, relative to that of unit Qoeo, suggests that deposits of unit Qte on the north side of Clear Creek may have accumulated during a younger pre-Bull Lake glaciation that occurred after about $620 \mathrm{ka}$. Glaciers during one or more pre-Bull Lake glaciations flowed $31 \mathrm{~km}$ down the Lake Creek valley to an altitude of about 2,800 $\mathrm{m}$ and $21 \mathrm{~km}$ or more down the valley of Clear Creek to an altitude of about 2,780 m. Estimated thickness is $1.5-30 \mathrm{~m}$

\section{Bedrock Units}

\section{Post-volcanic Sediments}

Dry Union Formation (lower Pliocene? and Miocene) - Deposits of the Dry Union Formation within the map area are exposed in small widely spaced outcrops and manmade cuts about $0.5-10 \mathrm{~m}$ high that range in altitude from about 2,780 to $2,940 \mathrm{~m}$. Unit consists chiefly of fluvial and fan deposits. Fluvial deposits probably were transported and deposited by perennial, through-flowing streams. Fan deposits consist chiefly of stream-channel alluvium of minor tributary streams (referred to hereafter as stream-channel alluvium), sheetflood alluvium, and debris-flow deposits. These fan deposits were deposited by ephemeral and intermittent streams, sheetfloods, and debris flows, respectively. Fluvial deposits are locally exposed in an area about $2 \mathrm{~km}$ wide and $7 \mathrm{~km}$ long that is parallel to and just west of the canyon cut in Proterozoic basement rocks by the Arkansas River. Fan deposits composed of stream-channel alluvium, sheetflood alluvium, and debris-flow deposits are locally exposed east of the Arkansas River north of Twobit Gulch as well as west of the Arkansas River at several localities. Deposits of unit Nd commonly are unconsolidated to moderately consolidated, non-sorted or poorly sorted, and crudely stratified to well stratified. Gravel is commonly clast supported and is locally matrix supported. Biotitebearing clasts are partly or completely disintegrated. Fluvial deposits of unit $\mathrm{Nd}$ north of Balltown consist chiefly of massive beds of coarse cobble gravel about $30 \mathrm{~m}$ thick that overlies finer-grained, lower-energy, fluvial deposits at least $60 \mathrm{~m}$ thick. The underlying exposed lower-energy fluvial deposits of unit $\mathrm{Nd}$ consist chiefly of pebbly sand, sandy pebble gravel, and slightly cobbly pebble gravel in lenses and layers about $3-200 \mathrm{~cm}$ thick. Fluvial deposits near the Granite Cemetery are at least $24 \mathrm{~m}$ thick. They consist chiefly of cobble gravel, cobbly pebble gravel, sandy pebble gravel, a subordinate amount of pebbly sand, and a minor amount of sandy silt in lenses and layers about 20-300 cm thick. Fluvial deposits, exposed in a small outcrop about $550 \mathrm{~m}$ south-southwest of the Granite Cemetery, overlie debris-flow(?) deposits of unit $\mathrm{Nd}$. Orientations of imbricated cobbles observed in one exposure, just west of the Granite Cemetery, suggest fluvial transport towards the southeast. Clasts in fluvial deposits are angular to subrounded. Stream-channel alluvium commonly consists of deposits of sand and gravel in lenses and layers of sand about 5-250 cm thick. Sand bodies locally contain lenses of pebble gravel, and gravel bodies locally contain lenses of pebbly sand. Stream-channel alluvium locally includes small channel-fill deposits about 30-210 cm thick. Two small channel-fill deposits, observed near the base of unit Nd north of Twobit Gulch, consist of small-pebble conglomerate that is weakly cemented by secondary calcium carbonate. Clasts commonly are angular. Sheetflood alluvium commonly consists of alternating layers of mud and layers of pebble gravel or pebbly sand. Muddy upper layers are about $1-15 \mathrm{~cm}$ thick and pebbly lower layers are about $5-25 \mathrm{~cm}$ thick. These deposits form depositional packages about $120-250 \mathrm{~cm}$ in total thickness. Debris-flow deposits commonly consist of layers of pebbly sand above layers of cobbly, sandy pebble gravel. Sandy upper layers are about $15-50 \mathrm{~cm}$ thick and gravelly lower layers are about 50-200 cm thick. Clasts in debris-flow deposits commonly are very angular and subangular. Original thickness of unit $\mathrm{Nd}$ is unknown, because the unit was deposited on an irregular surface and the top of the unit is eroded (Tweto, 1961). Thickness based on outcrop and drill-hole data (Tweto, 1978; D.A. Ostenaa, S.L. Losh, and A.R. Nelson, Bureau of Reclamation, Denver, Colo., written commun., 1981) is at least $240 \mathrm{~m}$ on the north side of the Twin Lakes Reservoir. Preserved thickness in the subsurface, about $11 \mathrm{~km}$ north of the map area, may be as much as $1,200 \mathrm{~m}$ (Tweto and Case, 1972) 
Volcanic Rocks

Reva Vesicular andesite flow (upper Oligocene) - Pinkish-brown, finely vesicular, massive andesite porphyry south of Twin Lakes Reservoir. Consists of about 25 percent plagioclase, both as small microlites and large (to $5 \mathrm{~mm}$ long) crystals, 6 percent augite, 2 percent hornblende, and 2 percent opaque minerals. Glassy matrix composes about 65 percent of rock. Previously mapped as Grizzly Peak Tuff by Fridrich and others (1998); however, no rhyolite tuff was observed, only rubbly blocks are exposed in two small areas about 1.7 $\mathrm{km}$ southwest of the Twin Lakes dam. New ${ }^{40} \mathrm{Ar} /{ }^{39} \mathrm{Ar}$ age on hornblende is $24.12 \pm 0.12 \mathrm{Ma}$ (sample GR11-711, table 3)

Hypabyssal Rocks

At least three suites of felsic intrusive rocks are recognized within the map area: (1) $\sim 65$ Ma rhyolite dikes, (2) 40 Ma felsic plutons and dikes, and (3) a 24 Ma rhyolite stock and inferred coeval microtonalite plug. Each is described below.

Perc Hypabyssal rhyolite of Clear Creek (late Oligocene) - Pale pinkish-gray, porphyritic rhyolite(?) poorly exposed on ridge near southeast corner of the map area. Composed of about 55 percent glass with abundant quartz and feldspar microlites. Phenocrysts as long as $3 \mathrm{~mm}$ are composed of about 25 percent fragmental quartz, 9 percent plagioclase, 10 percent sanidine, 1 percent biotite, and trace opaque minerals. Contains many rounded fragments and clasts of Proterozoic gneiss as long as $1.5 \mathrm{~cm}$. Locally contains small vugs. Rhyolitic composition inferred from phenocryst ratios. New ${ }^{40} \mathrm{Ar} /{ }^{39} \mathrm{Ar}$ age on feldspar (sanidine?) is $24.3 \pm 0.6 \mathrm{Ma}$ (sample GR11-756, table 3)

Pedt Microtonalite (late Oligocene?) - Gray, fine-grained, massive, poorly exposed rock consisting of a mosaic of about 20 percent anhedral quartz, 65 percent very sericitized plagioclase, 8 percent biotite (almost entirely altered to chlorite, epidote, and hematite), 4 percent opaque minerals, and 3 percent secondary muscovite. Occurs only as float, just west of hypabyssal rhyolite pluton (PErc) near southeast corner of the map area

Pewf Felsic plutons and dikes of Winfield Peak and Middle Mountain of Fridrich and others (1998) (middle Eocene) - White to pale-gray, dull to vitreous, mostly porphyritic, very fine-grained to aphanitic, massive to weakly flow-foliated dikes and small stocks mainly south of Twin Lakes Reservoir. All samples contains about 2 percent equant quartz phenocrysts as long as $2 \mathrm{~mm}$, and most samples contain $2-3$ percent white, strongly sericitized plagioclase phenocrysts as long as $2 \mathrm{~mm}$. Locally, vuggy or vesicular. Some dikes have non-porphyritic chilled margin. In places weathers pinkish-orange. Rhyodacitic or dacitic in composition. New ${ }^{40} \mathrm{Ar} /{ }^{39} \mathrm{Ar}$ age on sanidine(?) is $42.25 \pm 0.13 \mathrm{Ma}$ (sample GR11-725, table 3)

$\mathrm{PEKr} \quad$ Rhyolite dikes (Paleocene or Late Cretaceous) - Two white to light-gray, glassy to finely crystalline rhyolite dikes as wide as about $10 \mathrm{~m}$ containing phenocrysts of bipyramidal quartz as long as about $5 \mathrm{~mm}$, feldspar, and biotite; fracture is conchoidal and glassy. Dikes are mapped about $1 \mathrm{~km}$ northwest and about $2 \mathrm{~km}$ north of the town of Granite. Whole-rock K-Ar age for dike east of Arkansas River (table 3) is 65.3 $\pm 2.4 \mathrm{Ma}$ (sample USGS(D)G-A-82, Marvin and others, 1989)

PEKi Felsic porphyry intrusive (Paleocene or Late Cretaceous) - One small stock east of Arkansas River in SE1/4, sec. 19, T. 11 S., R. 79 W. near the eastern boundary of the map area. Consists of very pale gray, massive, porphyritic felsite composed of about 65 percent very fine-grained sugary white matrix, about 20 percent anhedral glassy quartz phenocrysts as long as $3 \mathrm{~mm}, 10$ percent muscovite flakes as long as $3 \mathrm{~mm}$, and 5 percent chalky-white (sericitic) plagioclase as long as $2 \mathrm{~mm}$; no visible mafic minerals. Also contains numerous small irregular vesicles, suggesting shallow emplacement. Rock is a high-aluminum rhyolite or dacite porphyry. Undated, but similarity and proximity to dated rhyolite dike (PEKr) suggest Paleocene or Late Cretaceous age 


\section{Proterozoic Igneous and Metamorphic Rocks}

YXp Pegmatite (Mesoproterozoic and (or) Paleoproterozoic) - Coarse-grained to very coarse grained, white to light-pink, inequigranular quartz-feldspar-mica rock that forms irregularly shaped, commonly zoned dikes and other intrusive bodies that cut all Proterozoic rocks in map area, but predominantly cuts Mesoproterozoic rocks. Small unmapped bodies cut rocks as old as Paleoproterozoic. Some microcline crystals may be longer than $0.5 \mathrm{~m}$; mica is mostly biotite, but locally includes or is composed entirely of muscovite. Accessory minerals include tourmaline, garnet, and opaque minerals. Unit consists predominantly of pegmatite, which commonly grades into and is intimately mixed with aplite, which locally forms separate dikes and other intrusive bodies. Aplite is similar 'in composition to pegmatite but is a pinkish-tan, fine- to medium-grained, leucocratic, equigranular rock

Monzogranite and quartz monzonite (Mesoproterozoic) - Small stocks of massive to foliated, generally gray to pinkish-gray, light-brown weathering, medium-grained monzogranite and subordinate quartz monzonite. Intrudes Mesoproterozoic rocks (predominantly granite of Granite, unit Ygrg) so age is Mesoproterozoic; may be satellite bodies of monzogranite of Langhoff Gulch (Ygl)

Ygl Monzogranite of Langhoff Gulch (Mesoproterozoic) - Gray, medium-grained, equigranular to inequigranular, massive to weakly flow-foliated, syenogranite, monzogranite, and granodiorite. Contains about 25-35 percent quartz, 20-40 percent plagioclase, 12-45 percent microcline, 4-20 percent biotite, 1-2 percent muscovite, trace to 1 percent sphene, and traces of zircon and apatite; locally contains sparse rutile and garnet. Modal analyses from 19 stained slabs indicate predominantly monzogranite composition. U-Pb zircon age from location, about $5 \mathrm{~km}$ southeast of the map area, is 1,445 $\pm 7 \mathrm{Ma}$ (Kellogg and others, 2013). In most locations unit weathers to distinctive reddish-brown to light grayish-brown, in rounded to blocky outcrops

Yglf Strongly foliated phase - Highly strained monzogranite of Langhoff Gulch that intruded, and appears to be interlayered with, inliers of biotite gneiss $(\mathrm{Xb})$. Rock is gray, mediumgrained, strongly foliated and locally contains zones of augen gneiss. Mapped in one area just east of Arkansas River, northeast of Lake Creek

Ygrg Granite of Granite (Mesoproterozoic) - Medium- to dark-gray to grayish-pink, coarsegrained, massive to moderately foliated monzogranite in the southern and eastern parts of the map area; locally porphyritic, with potassium feldspar phenocrysts as long as about $3 \mathrm{~cm}$. Tends to be more mafic to west, where rock grades into granodiorite mapped as Paleoproterozoic Denny Creek Granodiorite (Fridrich and others, 1998) that was originally named Denny Creek Granodiorite Gneiss (Barker and Brock, 1965). U-Pb zircon (SHRIMP) age from an area north of Clear Creek that was previously mapped as Denny Creek Granodiorite is $1,434 \pm 7 \mathrm{Ma}$ (sample GR10-511, table 3), statistically identical to an age from a monzogranite sample near the town of Granite of $1,436 \pm 6 \mathrm{Ma}$ (sample WRP-03-6B, table 3). These two ages are statistically identical to those from the granite of Elephant Rock (Kellogg and others, 2013), mapped $6.5 \mathrm{~km}$ southeast of the map area which in addition to the similarity in petrography, suggests that both plutons were derived from the same magma source. Granite of Granite is mapped extensively south of the Twin Lakes Reservoir and in one small outcrop along the north shore of the reservoir

Granitic gneiss (Paleoproterozoic) - Light- to medium-gray, fine- to medium-grained, weakly to strongly foliated monzogranite, granodiorite, tonalite, and trondhjemite gneiss. Composed mostly of 25-30 percent undulatory quartz, 35-60 percent oligoclase, trace to 25 percent microcline, $5-15$ percent biotite, $1-2$ percent opaque minerals, $0-3$ percent hornblende, $0-1$ percent muscovite, and trace amounts of zircon, apatite, and garnet. Granitic gneiss is closely interlayered with biotite gneiss $(\mathrm{Xb})$ and leucocratic gneiss (XIg). Grades in places to layered gneiss resembling biotite gneiss $(\mathrm{Xb})$. Similar rocks in the Gore and Tenmile Ranges, about $50 \mathrm{~km}$ north of the map area, (Kellogg and others, 2011) and in the Front Range, about $90 \mathrm{~km}$ northeast of the map area, (Kellogg and others, 2008) have SHRIMP U-Pb zircon ages between about 1,770 Ma and 1,755 Ma. Mapped in one 5-km long, northeast-trending body about $1 \mathrm{~km}$ south of the Twin Lakes Reservoir 
Xlg Leucogranite gneiss (Paleoproterozoic) - Light-gray to almost white, medium-grained, moderately foliated monzogranite or granodiorite orthogneiss, with less than 5 percent biotite. Foliation strikes east-northeast. Mapped east and west of Flume Creek, about 1 $\mathrm{km}$ south of Twin Lakes Reservoir

Biotite gneiss (Paleoproterozoic) - Mostly gray to dark-gray, fine- to medium-grained, moderately foliated to strongly foliated and layered biotite gneiss. Migmatitic in most places; contains numerous light-colored layers and lenses (leucosomes) typically $0.1-10 \mathrm{~cm}$ thick, although locally may be much thicker. In most outcrops, leucosome bodies form less than half of rock, have sharp contacts with host rock, show much pinch and swell, and are locally strongly folded. Leucosomes are composed of equigranular, massive to weakly foliated, white to light-gray microcline-plagioclase-quartz rock containing less than 5 percent biotite; accessory minerals are muscovite, opaque minerals, sphene, apatite, garnet, and zircon. Forms large inliers in monzogranite of Langhoff Gulch (Ygl) along and east of the Arkansas River and a large northeast-trending body about $1.5 \mathrm{~km}$ south of the Twin Lakes Reservoir. Some areas mapped as biotite gneiss include small bodies of granitic rock. Unit undated in map area, but similar rocks in the Gore Range and Front Range north and northeast of the map area, respectively, have U-Pb melanosome ages on zircons of about 1,785-1,750 Ma (Kellogg and others, 2008, 2011). These ages represent those of the source rocks from which detritus that composes the sedimentary protolith was derived. In these same areas, $\mathrm{U}-\mathrm{Pb}$ zircon geochronology indicates that formation of migmatite (partial melting) occurred about 1,695 Ma (Kellogg and others, 2011)

Xhg Hornblende gneiss and amphibolite (Paleoproterozoic) —Dark-gray to black, weakly to strongly foliated, layered, mostly medium grained, hornblende-plagioclase gneiss and amphibolite, locally containing variable, but small, amounts of biotite, quartz, and augite. Commonly has black-and-white mottled texture due to weathered plagioclase (white) and hornblende (black). Amphibolite contains $>50$ percent amphibole. Closely interlayered in places with more felsic gneissic rocks. Occurs as one small body about $5 \mathrm{~km}$ south of the Twin Lakes Reservoir. Many small, unmapped bodies of Xhg are included with other units, such as biotite gneiss $(\mathrm{Xb})$

Xgb Gabbro (Paleoproterozoic) - Very dark green hornblende-biotite gabbro containing about 50 percent medium-grained calcic plagioclase, hornblende, and biotite in a dark-green, chert-like (serpentinized?) matrix. Exposed as one small (about $140 \mathrm{~m}$ long) intrusive body, interpreted as injected along or near contact between granite of Granite (Ygrg) and monzogranite (Ygr) in southwest part of the map area 

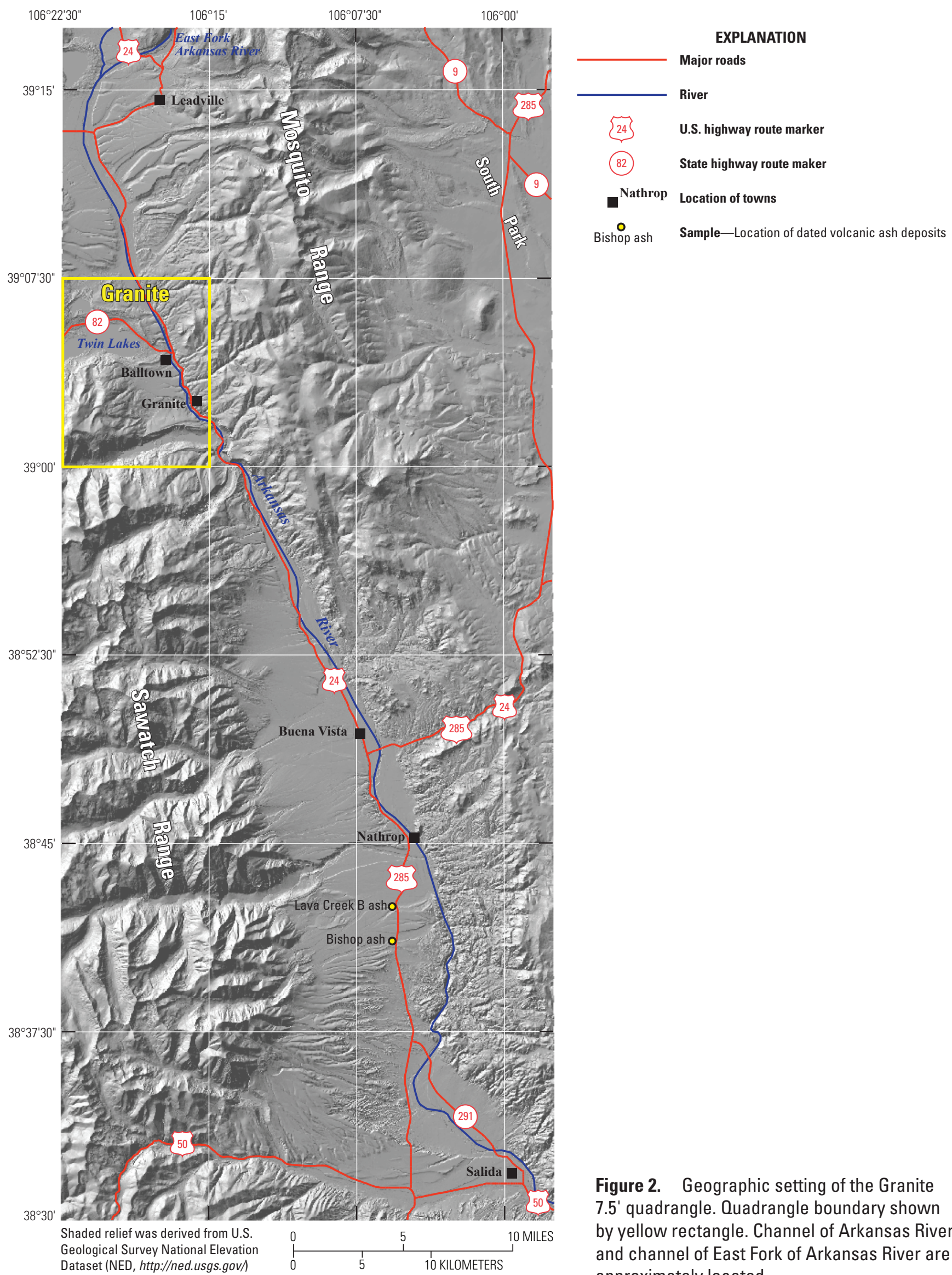

Figure 2. Geographic setting of the Granite 7.5' quadrangle. Quadrangle boundary shown by yellow rectangle. Channel of Arkansas River and channel of East Fork of Arkansas River are approximately located. 
Table 2. Approximate height, in meters, of the top of gravelly stream alluvium of middle Pleistocene to Holocene age above the Arkansas River and its major east-flowing tributaries near the Arkansas River in the Granite $7.5^{\prime}$ quadrangle.

$[-$, no deposits along stream $]$

\begin{tabular}{lccccc}
\hline \multicolumn{1}{c}{ Map unit } & Arkansas River & Lake Creek & Clear Creek & Cache Creek & Corske Creek \\
\hline Qva & $1-2$ & $1-2$ & $1-2$ & $1-2$ & $1-2$ \\
Qopy & $2-12$ & $2-7$ & $2-3$ & $2-3$ & $2-3$ \\
Qopo & $18-24$ & 18 & - & - & - \\
Qoby & 37 & - & - & - & - \\
Qobo & 43 & - & - & - & - \\
Qoey & $55-61$ & - & - & - & - \\
& $67-72$ & - & - & - & - \\
\hline
\end{tabular}

Table 3. Summary of isotopic ages for bedrock in the Granite 7.5' quadrangle.

$\left[\mathrm{All}{ }^{40} \mathrm{Ar} /{ }^{39} \mathrm{Ar}\right.$ analyses performed in Denver, Colorado, by M.A. Cosca (USGS); all ${ }^{207} \mathrm{~Pb} /{ }^{206} \mathrm{~Pb}$ analyses performed in joint USGS-Stanford SHIRMP facilities in Menlo Park, California, by W.R. Premo (USGS); whole-rock K-Ar age by Marvin and others (1989). Abbreviations: feld, feldspar; hb, hornblende; san, sanidine; WR, whole rock; zr, zircon]

\begin{tabular}{|c|c|c|c|c|c|c|}
\hline Sample No & Rock name & $\begin{array}{c}\text { Map } \\
\text { symbol }\end{array}$ & $\begin{array}{l}\text { Location } \\
\text { (UTM)* }\end{array}$ & $\begin{array}{c}\text { Mineral } \\
\text { analyzed }\end{array}$ & Technique & $\begin{array}{c}\text { Age } \\
\mathrm{Ma}\end{array}$ \\
\hline GR11-711 ${ }^{1}$ & vesicular andesite flow & Peva & 0385593E & $\mathrm{hb}$ & ${ }^{40} \mathrm{Ar} /{ }^{39} \mathrm{Ar}$ & $24.12 \pm 0.12$ \\
\hline \multirow[t]{2}{*}{ GR11-756 ${ }^{1}$} & hypabyssal rhyolite & Perc & 0390236E & feld (san?) & ${ }^{40} \mathrm{Ar} /{ }^{39} \mathrm{Ar}$ & $24.3 \pm 0.6$ \\
\hline & & & $4318028 \mathrm{~N}$ & & & \\
\hline GR11-725' & & & $4324141 \mathrm{~N}$ & & & \\
\hline \multirow[t]{2}{*}{ USGS(D)G-A- $82^{2}$} & rhyolite dike & $\mathrm{PEKr}$ & 0391371E & WR & $\mathrm{K}-\mathrm{Ar}$ & $65.3 \pm 2.4$ \\
\hline & & & $4324395 \mathrm{~N}$ & & & \\
\hline \multirow[t]{2}{*}{ GR10-511 ${ }^{1}$} & granite of Granite & Ygrg & 0385707E & $\mathrm{zr}$ & ${ }^{207} \mathrm{~Pb} /{ }^{206} \mathrm{~Pb}$ & $1,434 \pm 7$ \\
\hline & & & $4319201 \mathrm{~N}$ & & & \\
\hline
\end{tabular}

${ }^{1}$ K.S. Kellogg sample number

${ }^{2}$ Marvin and others (1989) sample number

${ }^{3}$ W.R. Premo sample number

*Datum: North America 1927 


\section{Geologic Setting of the Granite 7.5' Quadrangle}

The Granite quadrangle spans the upper Arkansas River valley, which is structurally controlled by normal faults within and along a north-northwest-trending graben that is part of the northern extent of the Rio Grande rift (Tweto, 1979a). The Rio Grande rift system is a zone of crustal extension that extends from northern Mexico (Chapin, 1979) to southern Wyoming (Mears, 1998), and possibly as far north as central Wyoming (Flanagan and Montagne, 1993). Paleoproterozoic and Mesoproterozoic basement rocks are exposed on both sides of the Arkansas River valley. Marine sediments, and mafic and felsic volcanic rocks were deposited locally in the central Rocky Mountain region, including the map area, between about 1,780 and 1,740 Ma. At about 1,715 to 1,700 Ma (Premo and others, 2007), these sediments and rocks were metamorphosed to amphibolite grade and were intruded and deformed by mostly calc-alkalic granitic rocks. These layered metasedimentary and metaigneous rocks commonly include biotite gneiss, granitic gneiss, hornblende gneiss, and minor amphibolite. Zircons from biotite gneiss of the Gore Range, about $50 \mathrm{~km}$ north of the map area, are 1,785-1,750 Ma (Kellogg and others, 2011). These are the ages of the source rocks from which the zircons were derived and therefore represent the maximum age of deposition of the sediments. Following metamorphism at about 1,750-1,730 Ma during the Paleoproterozoic, batholiths and smaller bodies of mostly granodiorite and monzogranite, referred to as the Routt Plutonic Suite of Tweto (Tweto, 1978), intruded the older layered rocks in and near the Granite quadrangle. By far the most voluminous intrusive rocks in the quadrangle are granitic rocks of the Berthoud Plutonic Suite of Tweto (Tweto, 1978), which were emplaced during the Mesoproterozoic. These rocks include the granite of Granite (Ygrg, two U-Pb zircon ages of $1,436 \pm 6 \mathrm{Ma}$ and $1,434 \pm 7 \mathrm{Ma}$, table 3 and the monzogranite of Langhoff Gulch (Ygl, one U-Pb zircon age of 1,446 $\pm 50 \mathrm{Ma}$; Kellogg and others, 2013).

No pre-Neogene sedimentary rocks are exposed in the Granite quadrangle (Tweto and Reed, 1973), probably due to uplift and erosion of the Sawatch Range during the Laramide orogeny or during post-Laramide regional epeirogenic uplift (Eaton, 2008). A thick section of Paleozoic rocks cut chiefly by normal faults is preserved on the east flank of the Mosquito Range immediately northeast of the Granite quadrangle (Tweto and others, 1978).

Numerous dikes and small intrusive stocks intrude the Proterozoic rocks in the quadrangle. These dikes may be as old as Late Cretaceous, based on one whole rock K-Ar age of $65.3 \pm 2.4 \mathrm{Ma}$ (table 3), from a rhyolite dike $2 \mathrm{~km}$ north of the town of Granite (Marvin and others, 1989). Dikes associated with the Twin Lakes pluton of Paleocene age have not been identified in the Granite quadrangle. The Twin Lakes pluton, emplaced just west of the Granite quadrangle, is composed chiefly of strongly porphyritic biotite granodiorite and associated compositionally layered rocks and aplite bodies
(Fridrich and others, 1998). One of the diorite dikes related to the pluton, about $15 \mathrm{~km}$ west of the Granite quadrangle, has a ${ }^{40} \mathrm{Ar} /{ }^{39} \mathrm{Ar}$ weighted-mean age on hornblende of $63.8 \pm 1.4 \mathrm{Ma}$ (Fridrich and others, 1998). A cluster of felsic dikes and small plutons of middle Eocene age were emplaced mainly south of the Twin Lakes Reservoir. One of the felsic plutons (PEwf) has $\mathrm{a}^{40} \mathrm{Ar} /{ }^{39} \mathrm{Ar}$ age of $42.25 \pm 0.13 \mathrm{Ma}$. A small hypabyssal rhyolite pluton ( $\mathrm{PErC}$ ), with a ${ }^{40} \mathrm{Ar} /{ }^{39} \mathrm{Ar}$ age of $24.3 \pm 0.6 \mathrm{Ma}$, is exposed near the southeast corner of the quadrangle. A small andesite lava flow (PEva), with a ${ }^{40} \mathrm{Ar} /{ }^{39} \mathrm{Ar}$ age of $24.12 \pm 0.12 \mathrm{Ma}$, overlies Paleoproterozoic rock $1 \mathrm{~km}$ south of the Twin Lakes Reservoir (see table 3).

One small felsic stock (PEKi) and two rhyolite dikes $(\mathrm{PEKr})$ north of the town of Granite were emplaced during the Laramide orogeny, a period of contractional tectonism and mountain building, that began in the area of the present-day Sawatch Range about 72-70 Ma during the Late Cretaceous (Tweto, 1975, 1980). Laramide structural features, such as thrust and reverse faults, have not been documented in the Granite quadrangle, but are regionally common (for example, Tweto, 1975, 1980; Kellogg and others, 2004).

Dominantly north-northwest-trending normal faults, that are down-to-the-east in the western two-thirds of the Granite quadrangle and down-to-the-west in the eastern one-third, resulted from crustal extension that probably began during the late Oligocene. Normal faults are characteristic of the northern part of the Rio Grande rift. The oldest syn-rift volcanic rocks in southern Colorado and northern New Mexico are about 26 Ma (Lipman and Mehnert, 1975; Chapin, 1988; Thompson and others, 1991; Chapin and Cather, 1994); they mark the approximate time of initial rifting. Three fission-track ages on apatite $(20.0 \pm 2.9,19.9 \pm 4.4$, and $16.0 \pm 2.4 \mathrm{Ma})$ for rocks of the Twin Lakes pluton, collected about 2-6 km west of the Granite quadrangle, are cooling ages that reflect the development of the upper Arkansas valley graben and associated significant uplift, erosion, and westward tilting of the east margin of the Sawatch Range during Miocene time (Bryant and Naeser, 1980). The age of the extensional faulting in the Granite quadrangle is not well constrained, and most fault scarps are highly degraded. Lidar imagery suggests that two, short, inferred normal faults about $1 \mathrm{~km}$ west of the Arkansas River may displace deposits as young as middle Pleistocene. Evidence of younger faulting is well expressed along the eastern margin of the Sawatch Range, near Cottonwood Creek and Eddy Creek, about 20 and $33 \mathrm{~km}$ south of the Granite quadrangle, respectively, where neotectonic studies suggest at least six surface-faulting events during the past 150,000-100,000 years; a recurrence interval of 10,000-40,000 years for significant surface displacement, and youngest displacement during the Holocene (Ostenaa and others, 1980, 1981).

The Arkansas valley within the Granite quadrangle is locally underlain by at least $240 \mathrm{~m}$ of basin-fill sediments of the Dry Union Formation (Nd) of Miocene and lower Pliocene(?) age. These deposits consist of unconsolidated to moderately consolidated fluvial and fan deposits composed chiefly of sand and gravel deposited during a period of 
widespread extension-related basin development and coeval basin sedimentation that is contemporaneous, in part, with sediments of the Santa Fe Group, Troublesome Formation, and Browns Park Formation in northern New Mexico and northern Colorado (Izett, 1975; Steven, 2002; McMillan and others, 2006).

Surficial deposits of Pleistocene and Holocene age are widespread in the Granite quadrangle, particularly in the valleys of Lake Creek and Clear Creek and on slopes underlain by the Dry Union Formation. During the Pinedale, Bull Lake, and pre-Bull Lake glaciations, large glaciers headed near the crest of the Sawatch Range west of the Granite quadrangle. They flowed $31 \mathrm{~km}$ down the valley of Lake Creek and $23 \mathrm{~km}$ down the valley of Clear Creek and deposited abundant till (Qtpy, Qtpo, Qtb, and Qte) and outwash gravel (Qopy, Qopo, Qoby, Qobo, Qoey, and Qoeo) that formed large moraines and extensive outwash terraces in and near the upper Arkansas River valley (Nelson and Shroba, 1998).

Outwash deposits formed during the Pinedale, Bull Lake, and pre-Bull Lake glaciations in the Granite quadrangle were deposited by the Arkansas River and by eastward-flowing tributary streams. The lithologic composition of the clasts in these deposits primarily reflects that of the main bedrock units in the glaciated headwaters of these streams. Outwash deposited by the Arkansas River is rich in clasts of granitic composition, porphyry, and pegmatite. It also contains subordinate amounts of light-colored, aphanitic intrusive rocks and gneiss, and a minor amount of quartzite. Outwash deposited by eastward flowing tributary streams are rich in clasts of granitic composition (including the strongly porphyritic biotite granodiorite of the Twin Lakes pluton) and gneiss. Deposits along Lake Creek and Corske Creek also contain a minor amount of ashflow tuff, rhyolite tuff, and other volcanic rocks of the Grizzly Peak caldera (Fridrich and others, 1991). Deposits along Clear Creek and Cache Creek also contain a minor amount of metasedimentary gneiss, schist, and thinly bedded gray quartzite (Fridrich and others, 1998). Clasts in outwash deposited by the Arkansas River are commonly angular to subrounded; whereas, those in outwash deposited by eastward-flowing tributary streams are commonly angular and subangular.

The glacier in the valley of Clear Creek impounded the Arkansas River and created large lakes in the Arkansas valley upstream of the glacier twice during the Pinedale glaciation, at about 19 and $18 \mathrm{ka}$ (Young and others, 2011). However, these lakes must have been short lived because neither the deposits that accumulated in these large lakes nor any geomorphic features (such as shorelines) associated with these lakes were observed within the Granite quadrangle. Floods caused by the failures of glacial-ice dams in the valley of Clear Creek at its confluence with the Arkansas River transported boulders greater than $10 \mathrm{~m}$ in mean diameter (Lee, 2010), and had estimated peak discharges of between 21,000 and $65,000 \mathrm{~m}^{3} / \mathrm{s}$ (Brugger and others, 2011).

Deposits of sandy silt and silty sand at least $20 \mathrm{~m}$ thick, penetrated by drill holes beneath deposits of till and outwash along the axis of the Twin Lakes dam (Tweto, 1978;
D.A. Ostenaa, S.L. Losh, and A.R. Nelson, Bureau of

Reclamation, Denver, Colo., written commun., 1981), probably record a proglacial or ice-marginal lake or lakes impounded by the glacier or by till in the valley of Lake Creek during the Pinedale glaciation. The only exposed glacio-lacustrine deposit, too small to show at map scale, is a gray massive silt exposed on the north shore of the Twin Lakes Reservoir about $2 \mathrm{~km}$ northwest of the Twin Lakes dam. This deposit was previously considered to be type-O Pearlette volcanic ash (Tweto, 1987); however, it only contains scattered shards of volcanic glass (J.L. Slate, USGS, oral commun., 2011) that probably were derived from volcanic ash in the Dry Union Formation.

Mass-movement deposits transported by creep, debris flows, landslides, rockfall, and solifluction are locally common in the Granite quadrangle. Large landslide deposits (Qls) along and north of the Twin Lakes Reservoir as well as the large landslide on the north side of Cache Creek are probably composed chiefly of material derived from sediments of the Dry Union Formation. The two large landslide deposits near the southwest corner of the Granite quadrangle are composed of rock fragments derived from granite bedrock that may have been weakened by faulting and deep-seated gravitational spreading.

Large placer-tailings deposits (pt) in the Granite quadrangle were formed between about 1860 and 1950 by hydraulic mining and other mining methods used to concentrate native gold (Parker, 1974a, 1974b). This gold that was produced primarily from glacial outwash and fluvial gravel in the Dry Union Formation, probably was derived chiefly from goldbearing veins in bedrock of the Sawatch Range. The largest placer-tailings deposits are along Cache Creek, west of the Granite Cemetery. Smaller deposits are present along Cache Creek east of the Granite Cemetery, along Lake Creek near its confluence with the Arkansas River, along the low reach of Corske Creek, and along minor, unnamed washes near the mouth of Lake Creek and in the area between Lake Creek and Cache Creek.

\section{Lithologic Characteristics of the Dry Union Formation in and near the Granite 7.5' Quadrangle}

Sediments of the Dry Union Formation (Nd) record the depositional history and architecture of extension-related structures, including the Blue River half graben near Breckenridge, Colo. (Tweto and others, 1978; Kellogg and others, 2011), the upper Arkansas valley graben between Leadville and Salida, Colo. (Scott, 1975; Scott and others, 1975; Tweto and others, 1978; Kellogg, 1999), the Pleasant Valley graben near Howard, Colo. (Taylor and others, 1975), and the north end of the San Luis basin near Poncha Pass (Van Alstine, 1968; Tweto, 1979b). Tweto (1961) defined the Dry Union Formation over 50 years ago, although much of what is known about the lithology of the Dry Union in the northern 
part of upper Arkansas valley graben only comes from brief descriptions by Tweto $(1961,1974 c, 1978$; Tweto and Case, 1972). The following text summarizes information on the genesis, particle-size characteristics, thickness, clast composition, and color of deposits that compose the upper part of the Dry Union Formation within an area south of Dry Union Gulch (see the USGS Leadville South and Granite 7.5' quadrangles) where sediments of the Dry Union Formation are well exposed (Tweto, 1961; McCalpin and others, 2012; this report).

Fluvial deposits commonly consist of cobble gravel, cobbly pebble gravel, pebble gravel, and sandy pebble gravel with a matrix of coarse sand that locally contains abundant granules. They also include deposits of non-pebbly to pebbly coarse to very coarse sand and finer-grained sediments that contain varying amounts of silt and clay (table 4). A $30-\mathrm{m}$ thick section composed of coarse cobble gravel north of Balltown contains a few thin $(30 \mathrm{~cm})$ lenses of coarse and very coarse sand and a few rounded boulders about $30-50 \mathrm{~cm}$ in diameter. Deposits of fluvial gravel just west of the Granite Cemetery locally contain thin $(25-70 \mathrm{~cm})$, roughly horizontal zones of light-orange (iron?) and zones of black (manganese?) coatings on clasts. The formation of these orange and black zones may be due to oxidation and reduction reactions associated with former fluctuating water tables. Gravelly fluvial deposits north of Balltown are rich in granitic clasts, whereas those near the Granite Cemetery also contain subordinate amounts of light-colored aphanitic intrusive rocks and a minor amount of white quartzite. White quartzite clasts, which com- monly have thick, tan oxidation rinds, probably were derived from sources north of the map area east of the Arkansas River (Tweto, 1974a, 1974b). Clasts in fluvial deposits are angular to subrounded and typically have a light-yellow patina not observed on clasts in deposits of outwash of late and middle Pleistocene age within the map area.

Stream-channel alluvium deposited by ephemeral and intermittent streams are similar in particle size to fluvial deposits, although the former commonly lacks deposits of cobble gravel (table 4) and subrounded clasts, and commonly contains more deposits of pebbly sand and sand than do typical fluvial deposits. Deposits of gravelly alluvium west of the Granite Cemetery are rich in light-colored aphanitic intrusive igneous rocks, clasts of granitic composition, vein quartz, and rhyolite tuff or shallow intrusive rock. Gravelly alluvium in other parts of the map area are rich in granitic clasts.

Deposits of sheetflood alluvium commonly consist of fining upward, rhythmically bedded couplets composed of alternating layers of mud and either pebble gravel or pebbly coarse sand. Muddy upper layers commonly consist of slightly clayey, very silty, very fine and fine sand or very fine sandy silt (table 4). Pebbly lower layers commonly consist of slightly sandy, granule-rich, pebble gravel with a medium to very coarse sand matrix, and locally consist of pebbly coarse and very coarse sand. The muddy sediments that compose some of the upper layers may have been deposited by hyperconcentrated flows. Muddy layers locally show evidence of minor small-scale syndepositional soft-sediment deformation as

Table 4. Estimated particle sizes of unconsolidated to moderately consolidated sediments of the Dry Union Formation in the Granite 7.5' quadrangle.

[Abbreviations: FD, fluvial deposits; SA, stream-channel alluvium deposited by ephemeral and intermittent streams; SF, sheetflood alluvium; DF, debris-flow deposits; Sl, slightly; X, observed at one or more sites - not observed]

\begin{tabular}{lcccc}
\hline \multicolumn{1}{c}{ Sediments } & FD & SA & SF & DF \\
\hline Cobble gravel & $\mathrm{X}$ & - & - & - \\
Cobbly pebble gravel & $\mathrm{X}$ & $\mathrm{X}$ & - & - \\
Cobbly sandy pebble gravel & - & - & - & $\mathrm{X}$ \\
Pebble gravel & $\mathrm{X}$ & $\mathrm{X}$ & $\mathrm{X}$ & - \\
Sandy pebble gravel & $\mathrm{X}$ & $\mathrm{X}$ & $\mathrm{X}$ & - \\
Non-pebbly to pebbly coarse and very coarse sand & $\mathrm{X}$ & $\mathrm{X}$ & $\mathrm{X}$ & - \\
Pebbly, sl. clayey, silty, coarse and very coarse sand & - & - & - & $\mathrm{X}$ \\
Pebbly, clean to sl. silty, medium to very coarse sand & $\mathrm{X}$ & - & - & - \\
Sl. pebbly, clean to silty, very fine to very coarse sand & - & $\mathrm{X}$ & - & - \\
Sl. silty to very silty, very fine to medium sand & $\mathrm{X}$ & - & - & - \\
Sl. clayey, very silty, very fine and fine sand & - & $\mathrm{X}$ & $\mathrm{X}$ & - \\
Very fine sandy silt & $\mathrm{X}$ & $\mathrm{X}$ & $\mathrm{X}$ & - \\
\hline
\end{tabular}


well as evidence of post-depositional down-slope creep that may have occurred under periglacial conditions during the Pleistocene. Clasts in sheetflood deposits commonly are very angular to angular.

Debris-flow deposits fine upward, commonly with an upper layer composed of pebbly, slightly clayey, silty, locally granule-rich, coarse and very coarse sand, and a lower layer composed of cobbly, sandy pebble gravel (table 4). Clasts in debris-flow deposits commonly are very angular to angular, and many are randomly oriented.

The matrix colors of deposits of the Dry Union Formation tend to vary with particle size (for particle sizes used see table 1). Deposits rich in silt commonly are unoxidized or reduced, probably due in part to their relatively high moisture-holding capacity (table 5). They are light gray (5Y $7 / 2$ and $2.5 \mathrm{Y} 7 / 2$ ) and pale yellow (5Y 7/3), and commonly have small yellow (10YR 8/6) and reddish-yellow (7.5YR 6/8) mottles. Deposits of sand and gravel are oxidized, typically very pale brown (10YR 7/3), pale brown (10YR 6/3), very pale brown (10YR 7/4), and light-yellowish brown (10YR 6/4) probably due in part to their relatively low moisture-holding capacity and the weathering of iron-bearing minerals such as biotite. Some deposits of sand and gravel are more strongly oxidized, and are pink (7.5YR 7/4), light brown (7.5YR 6/4), and strong brown (7.5YR 5/6).

Although thin beds and lenses of volcanic ash are locally exposed in the Dry Union Formation in the western portion of the Leadville mining district (Tweto, 1961) and near Salida, Colo. (Van Alstine, 1969, 1974; Shannon and McCalpin, 2006), thin lenses of volcanic ash or fine ashy sediment were only observed within the map area by Shroba in 1974 in a large trench excavated for penstocks near the southeast corner of the Mount Elbert Forebay, now covered by artificial fill (af). A few lenses of volcanic ash were penetrated by drill holes near the north end of the trench (D.A. Ostenaa, S.L. Losh, and A.R. Nelson, Bureau of Reclamation, Denver, Colo., written commun., 1981).

Eolian, lacustrine, or playa deposits were not observed within the map area. However, deposits of sandy silt and clay were penetrated by drill holes beneath and slightly north of the Mt. Elbert power plant on the north shore of the Twin Lakes Reservoir (D.A. Ostenaa, S.L. Losh, and A.R. Nelson, Bureau of Reclamation, Denver, Colo., written commun., 1981). Silty sediments (Nd) at least $11.5 \mathrm{~m}$ thick, which contain one or more thin $(35 \mathrm{~cm})$ lenses of volcanic ash and one or more thin $(40 \mathrm{~cm})$ lenses of granule-rich very coarse sand, are locally exposed on the north side of Box Creek about $1 \mathrm{~km}$ north of the map area. These sediments may have been deposited in a body of water or in a wetland environment on a floodplain during shallow overbank flooding in an area away from the active stream channel. They lack the induration and strong reddish brown to red colors characteristic of sediments deposited in alkaline, saline water (Chapin and Lindley, 1986). Some of the deposits beneath and near the power plant and on the north side of Box Creek may be similar in origin to the thick fine-grained deposits, penetrated by miners in deep (25-245 m) mine shafts excavated in the Dry Union Formation in the western part of the Leadville mining district. These fine-grained deposits were originally called "lake beds" (Emmons and others, 1886; Emmons and Irving, 1907; Emmons and others, 1927). They were later described as consisting predominantly of beds of sandy and pebbly silt, lenses of sand, clay, and gravel, and thin beds of volcanic ash deposited chiefly in alluvial fans (Tweto, 1961, 1974c). Some of the silt-sized material in thick fine-grained deposits in the western part of the Leadville mining district may be similar in origin to that of abundant siltstone beds of the upper Oligocene to upper Miocene Troublesome Formation exposed

Table 5. Dry Munsell colors of unconsolidated to moderately consolidated sediments of the Dry Union Formation in the Granite 7.5' quadrangle.

[Abbreviations: FD, fluvial deposits; SA, stream-channel alluvium deposited by ephemeral and intermittent streams; SF, sheetflood alluvium; DF, debris-flow deposits; X, dry matrix color observed at one or more sites; - , color not determined or not observed]

\begin{tabular}{llllll}
\hline \multicolumn{1}{c}{ Color } & $\begin{array}{c}\text { Munsell } \\
\text { notation }\end{array}$ & FD & SA & SF & DF \\
\hline Pale yellow & 5 Y 7/3 & - & $\mathrm{X}$ & - & - \\
Light gray & 5 Y 7/2 & $\mathrm{X}$ & $\mathrm{X}$ & - & - \\
Light gray & 2.5 Y 7/2 & - & $\mathrm{X}$ & - & - \\
Very pale brown & 10 YR 7/4 & $\mathrm{X}$ & $\mathrm{X}$ & - & - \\
Very pale brown & 10 YR 7/3 & $\mathrm{X}$ & $\mathrm{X}$ & $\mathrm{X}$ & $\mathrm{X}$ \\
Light yellowish-brown & 10 YR 6/4 & - & $\mathrm{X}$ & - & - \\
Pale brown & 10 YR 6/3 & $\mathrm{X}$ & - & - & - \\
Pink & 7.5 YR 7/4 & $\mathrm{X}$ & $\mathrm{X}$ & - & $\mathrm{X}$ \\
Light brown & 7.5 YR 6/4 & - & $\mathrm{X}$ & - & - \\
Strong brown & 7.5 YR 5/6 & $\mathrm{X}$ & - & - & - \\
\hline
\end{tabular}


in the Fraser and Granby basins and in Middle Park about $90 \mathrm{~km}$ north of the map area. Limited particle-size and sorting data for siltstones in the Troublesome Formation in the Fraser basin suggests that these siltstones are composed chiefly of loess or loess-rich alluvium (Shroba and others, 2010).

A few of the deposits composed of very silty, very fine to medium sand south of the Mount Elbert Forebay have blocky, soil-like structure. These deposits may be weakly developed cambic B soil horizons that formed in paleosols. These deposits or incipient soil horizons lack clay films, which are commonly observed in argillic B soil horizons (Soil Survey Staff, 1999). Near Dry Union Gulch about $5 \mathrm{~km}$ north of the map area, McCalpin and others (2012) have identified two paleosols with clayey, reddish-brown, argillic B horizons preserved in the exposed upper part of the Dry Union Formation. Neither argillic nor calcic paleosol horizons were observed within the map area.

\section{Age of the Dry Union Formation}

The age of the Dry Union Formation in the Leadville area is not well known (Tweto, 1961). Well exposed beds near Salida, Colo., near the southern end of the upper Arkansas valley graben, locally contain abundant remains of fossil mammals and deposits of volcanic ash that suggest a Miocene age. G.E. Lewis considered the fossils identified near Salida (Van Alstine and Lewis, 1960; Van Alstine, 1969, 1974) such as Neohipparion sp. (three-toed horse) to be of Pliocene age, but they are now considered to be of Miocene age based on the current subdivision of Neogene time (U.S. Geological Survey Geological Names Committee, 2010). The oldest fossil mammals collected from the Dry Union Formation near Salida (fig. 2) are of Barstovian age (Steven and others, 1997) and therefore they are probably no older than about 15.9 Ma. The youngest fossil mammal collected from the Dry Union Formation, located in Adobe Park about $5 \mathrm{~km}$ northwest of Salida, is Ceratogaulus hatcheri (K.C. McKinney, USGS, Denver, Colo., written commun., 2012). The range in age of this extinct rodent is about 6-5 Ma (Hopkins, 2005).

A deposit of gray vitric ash about $1 \mathrm{~km}$ south of Salida has a composition that is typical of ashes erupted from the Twin Falls volcanic field in Idaho between about 10.5 and 8.5 Ma (Xu and others, 2001). Two other ash deposits in older, clayey, lacustrine(?) sediments of the Dry Union Formation (Shannon and McCalpin, 2006), about $12 \mathrm{~km}$ west of Salida, yielded radiogenic argon ages of $14.2 \pm 1.4$ and $13.3 \pm 0.2 \mathrm{Ma}$ (Hubbard and others, 2001).

The range in age of Ceratogaulus hatcheri along with the ages of the volcanic ashes investigated by $\mathrm{Xu}$ and others (2001) and Hubbard and others (2001) suggest that some of the sediments in the Dry Union Formation near Salida are coeval with those of the Ash Hollow Formation of the Ogallala Group in the northern part of the High Plains, which ranges in age from 13 to about $6 \mathrm{Ma}$ (Perkins and others, 1995).
The older, clayey ash-bearing sediments west of Salida may be correlative, in part, with the Pojoaque Member of the Tesuque Formation (Santa Fe Group), Troublesome Formation, North Park Formation, and Browns Park Formation. The Pojoaque Member of the Tesuque Formation, at or near its type section north of Santa Fe, New Mexico, contains a tephra layer near the middle of the member that yielded a weighted-mean ${ }^{40} \mathrm{Ar} /{ }^{39} \mathrm{Ar}$ age of $13.7 \pm 0.18 \mathrm{Ma}$ (Izett and Obradovich, 2001). The Troublesome Formation in Middle Park in north-central Colorado contains eight tuffs that have ${ }^{40} \mathrm{Ar} /{ }^{39} \mathrm{Ar}$ ages on sanidine and plagioclase that range from 23.5 to $11.0 \mathrm{Ma}$ and fossil mammals that range in age from latest Arikareean to early Clarendonian (Izett and Obradovich, 2001). The North Park Formation in North Park in northcentral Colorado locally contains a rhyolitic tuff that has a mean ${ }^{40} \mathrm{Ar} /{ }^{39} \mathrm{Ar}$ age on sanidine of $28.17 \pm 0.05 \mathrm{Ma}$ (E.E. Larson, Professor Emeritus, Univ. of Colo. at Boulder, written commun., 2013) and locally contains fossil mammals of late Hemingfordian age (Hail and Lewis, 1960) and Barstovian age (Montagne and Barnes, 1957; Montagne, 1991; Steven and others, 1997). The upper part of the Browns Park Formation, preserved in a half-graben (Mears, 1998) near Saratoga in south-central Wyoming, contains two pumicite layers that have ${ }^{40} \mathrm{Ar} /{ }^{39} \mathrm{Ar}$ weighted-mean ages of $15.86 \pm 0.04$ on biotite and $14.54 \pm 0.04 \mathrm{Ma}$ on anorthoclase and fossil mammals of Barstovian and Hemingfordian ages (Montagne, 1991). The Browns Park Formation in northwestern Colorado, west of the Park Range, locally contains air-fall tuffs dated by fission-track, $\mathrm{K} / \mathrm{Ar}$, and ${ }^{40} \mathrm{Ar} /{ }^{39} \mathrm{Ar}$ methods that range in age from 24.8 to 7.2 Ma (Izett and others, 1970; Winkler, 1970; Izett, 1975; Naeser and others, 1980; Snyder, 1980a; Snyder, 1980b; Luft, 1985; Honey and Izett, 1988).

The age of the sediments of the Dry Union Formation that underlie the older, clayey, ash-bearing sediments west of Salida is unknown. The former may be correlative, in part, with sediments of the Arikaree Group in western Nebraska that range in age from about 29 to $18 \mathrm{Ma}$ (Swinehart and Diffendal, 1995; Tedford and others, 2004).

The Dry Union Formation near Salida is younger than the Browns Canyon Formation (Van Alstine, 1969). Remnants of the Browns Canyon Formation, composed predominantly of thin-bedded tuffaceous siltstone, are exposed in a $0.2 \mathrm{~km}^{2}$ area about $13 \mathrm{~km}$ northwest of Salida where they contain plant fossils similar to those preserved in sediments of the Creede Formation in southwestern Colorado (Van Alstine, 1969). Sediments of the Creede Formation were deposited between 26.8 and $26.3 \mathrm{Ma}\left({ }^{40} \mathrm{Ar} /{ }^{39} \mathrm{Ar}\right.$ ages on sanidine from underlying and overlying volcanic units, Lanphere, 2000), during the late Oligocene.

The deposition of the Dry Union Formation in the southern part of the upper Arkansas valley graben postdates the inception of rift-related faulting and disruption of a former northeast-flowing stream in the Trout Creek paleovalley (Epis and other, 1976; Tweto, 1978; Leonard and others, 2002), $8 \mathrm{~km}$ southeast of Buena Vista, Colo. (fig. 2), and postdates the deposition of the Brown Park Formation (Van Alstine, 
1969). Fluvial transport in the paleovalley ceased sometime after clasts composed of rhyolite of Bald Mountain were deposited in sediments of the Wagontongue Formation in South Park (Tweto, 1978), about $20 \mathrm{~km}$ northeast of Buena Vista. Transport and deposition of these clasts occurred sometime after the eruption of the rhyolite of Bald Mountain at about 30.4 Ma (on sanidine in older flow) and 28.9 Ma (on anorthoclase in younger flow; McIntosh and Chapin, 2004).

The radiometric ages of the rhyolite of Bald Mountain (McIntosh and Chapin, 2004) suggest that the inception of riftrelated faulting and deposition in the area near the Trout Creek paleovalley began after 30.4 or $28.9 \mathrm{Ma}$. The recognition of similar plant fossils in the Browns Canyon Formation and the Creede Formation suggests that the inception of rift-related faulting and deposition of the Browns Canyon Formation may have begun as early as the late Oligocene. A late Oligocene age for the inception of rift-related faulting and deposition in the upper Arkansas valley graben is in accord with the age of about $26 \mathrm{Ma}$ for the inception of rift-related volcanism recorded by a thick series of mafic lavas preserved in the San Luis Hills in the central part of the San Luis basin (Thompson and others, 1991), about $135 \mathrm{~km}$ southeast of the southern margin the upper Arkansas valley graben.

\section{Brief History of Placer-gold Mining in the Granite 7.5' Quadrangle}

Some of the placer-gold mining areas within the map area have produced significant amounts of gold (table 6) and are among the richest in the State of Colorado. The following history was summarized chiefly from reports by Parker (1974a, 1974b, 1992). Gold was first discovered in deposits along Cache Creek in 1859 (Henderson, 1926) or 1860 (Emmons and others, 1886). The news of the placer gold discovery along Cache Creek spread rapidly. By the end of 1860, gold was discovered in deposits elsewhere within the map area, such as near the head of Lost Canyon, in the area between Cache Creek and Lake Creek, and near the mouth of Lake Creek. Between about 1859 or 1860 and 1883, placer gold was produced chiefly by hand methods and by ground sluicing. Gold production along Cache Creek, and possibly at small placer-mining areas north of Cache Creek, was increased in 1863 by water from Lake Creek that was conveyed by the Arlington ditch on the south side of Lake Creek. The Cache Creek ditch, which conveyed water from Big Willis Gulch (about $1 \mathrm{~km}$ west of map area) to small placer workings at and east of Flume Creek, probably was completed prior to 1900. Hydraulic mining within the map area began in 1884 with the completion of a ditch, tunnel, and flume, all of which conveyed water from the Clear Creek drainage to the Cache Creek placer-mining area. Hydraulic mining along Cache Creek continued from 1884 to 1917 when mining ceased.
Placer-mining and gold production significantly decreased during and after 1911 as the result of a lawsuit filed by the City of Pueblo and various water districts in the lower Arkansas River valley in 1910 against the company that was carrying out hydraulic mining operations along Cache Creek. The lawsuit, possibly one of the first environmental lawsuits in the State of Colorado, was filed because significant amounts of sediment generated by placer-mining along Cache Creek was flowing into and degrading the water quality of the Arkansas River.

Between 1860 and 1898, gold was produced by hand methods from bouldery outwash deposits of Pinedale age along Lake Creek east of the Twin Lakes. Ditches that conveyed water from Lake Creek facilitated hydraulic mining near the mouth of Lake Creek, and in areas north and south of Lake Creek, between about 1898 and 1908. Abundant boulders in the surficial deposits near the mouth of Lake Creek made hydraulic mining and the extraction of gold difficult.

During the early 1930s and periodically thereafter, gold was produced again by hand methods near the mouth of Lake Creek. A minor amount of dredging was done at the confluence of Lake Creek and the Arkansas River, and along the Arkansas River north of Granite during or slightly after 1927. Although gold may have been discovered along Corske Creek during the 1860 s, substantial gold production did not begin until dredging started in 1915. Dredging along and near the lower reach of Corske Creek was carried out during 19151917, 1924-1926, and 1947-1950. A dragline was also used to mine gold in this area during 1934-1942.

Placer gold within the map area was probably derived chiefly from gold-bearing veins in bedrock in the Lake Creek drainage (Howell, 1919) and near the head of Lost Canyon, which is located west of the Cache Creek drainage. Goldbearing veins near Gordon Gulch (Gese and Scott, 1993; Cappa and Bartos, 2007), on the north side of the Lake Creek valley near Parry Peak, may have been a major source of the placer gold that was mined along and near the lower reach of Corske Creek. In placer-gold mining areas underlain by Proterozoic bedrock, such as along Cache Creek, the highest concentrations of gold are located in sediments that are a few centimeters to about $4.5 \mathrm{~m}$ above the bedrock. However, in areas underlain by silty and clayey sediments of the Dry Union Formation, such as along Corske Creek, much of the gold is concentrated in outwash deposits about $15 \mathrm{~cm}$ or less above the top of the Dry Union Formation.

Minor amounts of gold are still being produced from deposits along Cache Creek and Lake Creek at its confluence with the Arkansas River. Present day recreational prospectors now use gold pans and small portable metal sluice boxes to concentrate and obtain gold from deposits worked about a century ago by miners, who used large heavy wooden sluice boxes and hydraulic mining equipment. 
Table 6. Summary of mining methods, years of gold production, and estimated minimum total value of gold production in the main areas of placer-gold production in the Granite 7.5' quadrangle. All of the information summarized from Parker (1974a, 1974b, 1992).

[All values for gold produced are those reported at the time of production in U.S. dollars. During the period of gold production, the official U.S. Government price of gold was $\$ 20.67$ per troy ounce $(\$ 0.67$ per gram) until January 30, 1934, when the price increased to $\$ 35.00$ per troy ounce ( $\$ 1.13$ per gram; Parker, 1974a). Values for the Cache Creek and Lake Creek areas do not include the minor amounts of gold produced in these areas during recent decades.]

\begin{tabular}{|c|c|c|c|}
\hline $\begin{array}{l}\text { Main areas } \\
\text { of placer-gold } \\
\text { production }\end{array}$ & Mining methods & $\begin{array}{l}\text { Years of gold } \\
\text { production }\end{array}$ & $\begin{array}{c}\text { Estimated minimum } \\
\text { total values of } \\
\text { gold production }\end{array}$ \\
\hline head of Lost Canyon & hand methods and ground slucing & $1860-1959^{1}$ & 200,000 \\
\hline Cache Creek & hand methods and ground slucing & $1860-1883$ & $1,000,000$ \\
\hline \multirow[t]{3}{*}{ Lake Creek } & hand methods & 1859 or $1860-1867$ & $55,000^{2}$ \\
\hline & hydraulic mining & 1898-1908 & \\
\hline & hand methods & early $1930 s^{3}$ & \\
\hline Corske Creek & dredging & $1947-1950$ & \\
\hline
\end{tabular}

\section{Acknowledgments}

The authors gratefully acknowledge the contributions and efforts of the following individuals. This report was improved by comments from David J. Lidke and Alan R. Nelson, U.S. Geological Survey (USGS), and Peter W. Birkeland, Professor Emeritus, University of Colorado at Boulder. Michael A. Cosca, USGS, dated Paleogene igneous rocks using the ${ }^{40} \mathrm{Ar} /{ }^{/ 9} \mathrm{Ar}$ method. Wayne R. Premo, USGS, dated Proterozoic igneous rocks using the ${ }^{207} \mathrm{~Pb} /{ }^{206} \mathrm{~Pb}$ zircon (SHRIMP) method. Jon Morrissey, District Ranger of the San Isabel National Forest, provided lodging at the Crystal Lakes Work Center. Local residents, including Bill Bockstiegel, Jack Nielsen, and Dennis O'Neill, facilitated our fieldwork by graciously granting us access to their properties. Dennis O'Neill generously provided images of vintage photographs from his collection of the Twin Lakes area. Jason P. Briner, University of Buffalo, Buffalo, New York, provided aerial photographs of the map area, two of which are on the pamphlet cover. Kevin C. McKinney, USGS, provided invaluable information on fossil vertebrates in the Dry Union Formation near Salida, Colo. Janet L. Slate, USGS, helped us resolve an issue concerning the origin of a silt deposit exposed on the north shore of the Twin Lakes Reservoir by determining that the deposit only contains scattered shards of volcanic glass and is not a deposit of volcanic ash as previously reported. Donald E. Englishman provided excellent assistance to the first author in the field during the summer of 1972.

\section{References Cited}

Barker, Fred, and Brock, M.R., 1965, Denny Creek Granodiorite Gneiss, Browns Pass Quartz Monzonite, and Kroenke Granodiorite, Mount Harvard quadrangle, Colorado, in Cohee, G.V., and West, W.S., eds., Changes in stratigraphic nomenclature by the U.S. Geological Survey, 1964: U.S. Geological Survey Bulletin 1224-A, p. A23-A26.

Barsch, Dietrich, 1987, The problem of ice-cored rock glaciers, in Giardino, J.R., Shroder, J.F., and Vitek, J.D., eds., Rock glaciers: London, Allen and Unwin, p. 45-53.

Benedict, J.B., 1970, Downslope soil movement in a Colorado alpine region-Rates, processes, and climatic significance: Arctic and Alpine Research, v. 2, p. 165-226.

Benedict, J.B., 1973a, Origin of rock glaciers: Journal of Glaciology, v. 12, p. 520-522.

Benedict, J.B., 1973b, Chronology of cirque glaciation, Colorado Front Range: Quaternary Research, v. 3, p. 584-599.

Benedict, J.B., 1985, Arapaho Pass - Glacial geology and archeology at the crest of the Colorado Front Range: Ward, Colo., Center for Mountain Archeology, Research Report, no. 3, 197 p. 
Birkeland, P.W., 1999, Soils and geomorphology: New York, Oxford University Press, 430 p.

Bohannon, R.G., and Ruleman, C.A., 2013, Geologic map of the Mount Sherman 7.5' quadrangle, Lake and Park Counties, Colorado: U.S. Geological Survey Scientific Investigations Map 3271, scale 1:24,000.

Brugger, K.A., 2007, Cosmogenic ${ }^{10} \mathrm{Be}$ and ${ }^{36} \mathrm{Cl}$ ages from late Pleistocene terminal moraine complexes in the Taylor River drainage basin, central Colorado, USA: Quaternary Science Reviews, v. 26, p. 494-499.

Brugger, K.A., Leonard, E. M., Lee, Keenan, and Bush, M.A., 2011, Discharge estimates for a glacial outburst paleoflood on the upper Arkansas River, Colorado, from an ice-dam failure model [abs.]: Geological Society of America Abstracts with Programs, v. 43, no. 4, p. 10.

Bryant, Bruce, and Naeser, C.W., 1980, Significance of fission-track ages of apatite in relation to the tectonic history of the Front and Sawatch Ranges, Colorado: Geological Society of America Bulletin, v. 91, no.3, p. 156-164.

Cappa, J.A., and Bartos, P.J., 2007, Geology and mineral resources of Lake County, Colorado: Colorado Geological Survey, Resources Series 42, 58 p., scale 1:50,000. [CD-ROM].

Capps, S.R., Jr., 1909, Pleistocene geology of the Leadville quadrangle, Colorado: U.S. Geological Survey Bulletin 386, 99 p.

Capps, S.R., Jr., and Leffingwell, E.D.K., 1904, Pleistocene geology of the Sawatch Range near Leadville, Colorado: Journal of Geology, v. 12, p. 698-706.

Chadwick, O.A., Hall, R.D., and Phillips, F.M., 1997, Chronology of Pleistocene glacial advances in the central Rocky Mountains: Geological Society of America Bulletin, v. 109, p. 1443-1452.

Chapin, C.E., 1979, Evolution of the Rio Grande rift-A summary, in Riecker, R.E., ed., Rio Grande rift: Tectonics and magmatism: American Geophysical Union, Washington, D.C., p. 1-5.

Chapin, C.E., 1988, Axial basins of the northern and central Rio Grande rifts, in Sloss, L.L., ed., Sedimentary coverNorth American craton: Boulder, Colorado, Geological Society of America, The Geology of North America, v. D-2, p. 165-170.

Chapin, C.E., and Cather, S.M., 1994, Tectonic setting of the axial basins of the northern and central Rio Grande rift, in Keller, G.R., and Cather, S.M., eds., Basins of the Rio Grande Rift - Structure, stratigraphy, and tectonic setting: Geological Society of America Special Paper 291, p. 5-25.
Chapin, C.E., and Lindley, J.I., 1986, Potassium metasomatism of igneous and sedimentary rocks in detachment terranes and other sedimentary basins_-Economic implications, in Beatty, B. and Wilkinson, P.A.K., eds, Frontiers in geology and ore deposits of Arizona and the Southwest: Arizona Geological Society Digest, v. 16, p. 118-126.

Cole, J.C., and Braddock, W.A., 2009, Geologic map of the Estes Park $30^{\prime} \times 60^{\prime}$ quadrangle, north-central Colorado: U.S. Geological Survey Scientific Investigations Map 3039, 56 p. pamphlet, scale 1:100,000.

Dahms, D.E., 2004, Relative and numeric age data for Pleistocene glacial deposits and diamictons in and near Sinks Canyon, Wind River Range, Wyoming: Arctic, Antarctic, and Alpine Research, v. 36, p. 59-77.

Davis, W.M., 1905, Glaciation of the Sawatch Range, Colorado: Bulletin of the Museum of Comparative Zoology: Cambridge, Massachusetts, Harvard University, v. 49 , p. $1-11$.

Eaton, G.P., 2008, Epeirogeny in the southern Rocky Mountains region-Evidence and origin: Geosphere, v. 4, no. 5, p. 764-784.

Emmons, S.F., Hillebrand, W.F., and Guyard, Antony, 1886, Geology and mining industry of Leadville, Colorado [with atlas]: U.S. Geological Survey Monograph 12, 770 p.

Emmons, S.F., and Irving, J.D., 1907, The downtown district of Leadville, Colorado: U.S. Geological Survey Bulletin 320, 75 p.

Emmons, S.F., Irving, J.D., and Loughlin, G.F., 1927, Geology and ore deposits of the Leadville mining district, Colorado: U.S. Geological Survey Professional Paper 148, 368 p.

Epis, R.C., Scott, G.R., Taylor, R.B., and Chapin, C.E., 1976, Cenozoic volcanic, tectonic, and geomorphic features of central Colorado, in Epis, R.C., and Weimer, R.J., eds., Studies in Colorado Field Geology: Professional Contributions of Colorado School of Mines, no. 8, p. 323-338.

Flanagan, K.M., and Montagne, John, 1993, Neogene stratigraphy and tectonics of Wyoming, in Snoke, A.W., Steidtmann, J.R., and Roberts, S.M., eds., Geology of Wyoming: Geological Survey of Wyoming Memoir no. 5, p. 573-607.

Fridrich, C.J., DeWitt, Ed, Bryant, Bruce, Richard, Steve, and Smith, R.P., 1998, Geologic map of the Collegiate Peaks Wilderness area and the Grizzly Peak caldera, Sawatch Range, central Colorado: U.S. Geological Survey Miscellaneous Investigations Series Map I-2565, 29 p., scale 1:50,000. 
Fridrich, C.J., Smith, R.P., DeWitt, Ed, McKee, E.H., 1991, Structural, eruptive, and intrusive evolution of the Grizzly Peak caldera, Sawatch Range, Colorado: Geological Society of America Bulletin, v. 103, p. 1160-1177.

Gese, D.D., and Scott, D.C., 1993, Regional mineral appraisal of the Leadville 2 degree quadrangle, U.S. Bureau of Mines Mineral Land Assessment Open-File Report 20-93, 324 p.

Hail, W.J., Jr., and Lewis, G.E., 1960, Probable late Miocene age of the North Park Formation in the North Park area, Colorado, in Short papers in the geological sciences, U.S. Geological Survey Professional Paper 400-B, p. B259-B260.

Hayden, F.V., 1874, [Seventh] Annual Report of the United States Geological and Geographical Survey of the Territories, embracing Colorado being a report of progress of the exploration for the year 1873: Washington, D.C., U.S. Government Printing Office, 718 p.

Hedlund, D.C., Nowlan, G.A., and Wood, R.H., II, 1983, Mineral resource potential map of the Buffalo Peaks Wilderness Study Area, Lake, Park, and Chaffee Counties, Colorado: U.S. Geological Survey Miscellaneous Field Studies Map MF 1628-A, 18 p., 1 sheet, scale 1:50,000.

Henderson, C.W., 1926, Mining in Colorado: A history of discovery, development and production: U.S. Geological Survey Professional Paper 138, 263 p.

Hilgard, E.W., 1892, A report on the relations of soil to climate: U.S. Department of Agriculture, Weather Bureau Bulletin 3, 59 p.

Honey, J.G., and Izett, G.A., 1988, Paleontology, taphonomy, and stratigraphy of the Browns Park Formation (Oligocene and Miocene) near Maybell, Moffat County, Colorado: U.S. Geological Survey Professional Paper 1358, 52 p.

Hopkins, S.S.B, 2005, The evolution of fossoriality and the adaptive role of horns in the Mylagaulidae (Mammalia: Rodentia): Proceedings of the Royal Society B, v. 272, p. 1705-1713, doi:10.1098/rspb.2005.3171.

Howell, J.V., 1919, Twin Lakes district of Colorado: Colorado Geological Survey, Bulletin 17, 108 p.

Hubbard, M.S., Oviatt, C.G., Kelly, Shari, Perkins, M.E., Hodges, K.V., and Robbins, Rebecca, 2001, OligoceneMiocene basin formation and modification in the northern Rio Grande rift; constraints for ${ }^{40} \mathrm{Ar} /{ }^{39} \mathrm{Ar}$, fission track, and tephrochronology [abs.]: Geological Society of America Abstracts with Programs, v. 33, no. 6, p. 257.

Isherwood, Dana, and Street, Alayne, 1976, Biotite-induced grussification of the Boulder Creek Granodiorite, Boulder County, Colorado: Geological Society of America Bulletin, v. 87 , p. $366-370$.
Izett, G.A., 1975, Late Cenozoic sedimentation and deformation in northern Colorado and adjoining areas, in Curtis, B.F., ed., Cenozoic history of the southern Rocky Mountains: Geological Society of America Memoir 144, p. 179-209.

Izett, G.A., Denson, N.M., and Obradovich, J.D., 1970, K-Ar age of the lower part of the Browns Park Formation, northwestern Colorado: U.S. Geological Survey Professional Paper 700-C, p. C150-C152.

Izett, G.A., and Obradovich, J.D., 2001, ${ }^{40} \mathrm{Ar} /{ }^{39} \mathrm{Ar}$ ages of Miocene tuffs in basin-fill deposits (Santa Fe Group, New Mexico, and Troublesome Formation, Colorado) of the Rio Grande rift system: The Mountain Geologist, v. 38 , p. $77-86$.

Izett, G.A., Obradovich, J.D., and Mehnert, H.H., 1988, The Bishop ash bed (middle Pleistocene) and some older (Pliocene and Pleistocene) chemically and mineralogically similar ash beds in California, Nevada, and Utah: U.S. Geological Survey Bulletin 1675, 37 p.

Izett, G.A., and Wilcox, R.E., 1982, Map showing localities and inferred distributions of the Huckleberry Ridge, Mesa Falls, and Lava Creek ash beds (Pearlette family ash beds) of Pliocene and Pleistocene age in the western United States and Canada: U.S. Geological Survey Miscellaneous Investigations Series Map I-1325, scale 1:4,000,000.

Johannes, W., and Gupta, L.N., 1982, Origin and evolution of a migmatite: Contributions to Mineralogy and Petrology, v. 79 , p. 114-123.

Kellogg, K.S., 1999, Neogene basins of the northern Rio Grande rift-Partitioning and asymmetry inherited from Laramide and older uplifts: Tectonophysics, v. 305, p. 141-152.

Kellogg, K.S., Bryant, Bruce, and Reed, J.C., Jr., 2004, The Colorado Front Range-Anatomy of a Laramide uplift, in Nelson, E.P., and Erslev, E.A., eds., Field trips in the southern Rocky Mountains, USA: Geological Society of America Field Guide 5, p. 89-108.

Kellogg, K.S., Lee, Keenan, Premo, W.R., and Cosca, M.A, 2013, Geologic map of the Harvard Lakes 7.5' quadrangle, Chaffee County, Colorado: U.S. Geological Survey Scientific Investigations Map 3267, 22 p., 1 sheet, scale 1:24,000.

Kellogg, K.S., Shroba, R.R., Bryant, Bruce, and Premo, W.R., 2008, Geologic map of the Denver West 30' $\times$ 60' quadrangle, north-central Colorado: U.S. Geological Survey Scientific Investigations Map 3000, 48 p., 1 sheet, scale $1: 100,000$. 
Kellogg, K.S., Shroba, R.R., Premo, W.R., and Bryant, Bruce, 2011, Geologic map of the east half of the Vail 30' $\times 60^{\prime}$ quadrangle, Eagle, Summit, and Grand Counties, Colorado: U.S. Geological Survey Scientific Investigations Map 3170, 49 p., 1 sheet, scale 1:100,000.

Lanphere, M.A., 2000, Duration of sedimentation of the Creede Formation from ${ }^{40} \mathrm{Ar} /{ }^{39} \mathrm{Ar}$ ages, in Bethke, P.M., and Hay, R.L., eds., Geological Society of America Special Paper 346, p. 71-76.

Lanphere, M.A., Champion, D.E., Christiansen, R.L., Izett, G.A., and Obradovich, J.D., 2002, Revised ages for tuffs of the Yellowstone Plateau volcanic field-Assignment of the Huckleberry Ridge Tuff to a new geomagnetic polarity event: Geological Society of America Bulletin, v. 114 , p. 559-568.

Lee, Keenan, 2010, Catastrophic glacial outburst floods on the Arkansas River, Colorado: The Mountain Geologist, v. 47, no. 2, p. 35-57.

Leonard, E.M., Hubbard, M.S., Kelly, S.A., Evanoff, Emmett, Siddoway, C.S., Oviatt, C.G., Heizler, Matt, and Timmons, Mike, 2002, High Plains to Rio Grande rift-Late Cenozoic evolution of central Colorado, in Lageson, D., ed., Science at the highest level: Boulder, Colorado Geological Society of America Field Guides, v. 3, p. 59-93.

Licciardi, J.M., and Pierce, K.L., 2008, Cosmogenic exposureage chronologies of Pinedale and Bull Lake glaciations in greater Yellowstone and Teton Range, USA: Quaternary Science Reviews: v. 26, p. 814-831.

Lipman P.W., and Mehnert, H.H., 1975, Late Cenozoic basaltic volcanism and development of the Rio Grande depression in the Southern Rocky Mountains, in Curtis, B.F., ed., Cenozoic history of the Southern Rocky Mountains: Geological Society of America Memoir 144, p. 119-154.

Lisiecki, L.E., and Raymo, M.E., 2005, A PliocenePleistocene stack of 57 globally distributed benthic $\delta^{18} \mathrm{O}$ records: Paleoceanography, v. 20, PA1003, 17 p., doi:10.1029/2004PA001071.

Luft, S.J., 1985, Airfall tuff in the Browns Park Formation, northwestern Colorado and northeastern Utah: The Mountain Geologist, v. 22, p. 110-127.

Marvin, R.F., Mehnert, H.H., Naeser, C.W., and Zartman, R.E., 1989, U.S. Geological Survey radiometric agesCompilation "C": Part five-Colorado, Montana, Utah, and Wyoming: Isochron/West, no. 53, p. 14-19.
Mason, Cody, Ruleman, C.A., and Kenny, Ray, 2011, Rate and timing of deglaciation using ${ }^{10} \mathrm{Be}$ cosmogenic nuclide surface exposure dating, Mt. Massive Wilderness, Colorado, USA [abs.]: Geological Society of America Abstracts with Programs, v. 43, no. 5, p. 65.

McCalpin, J.P., Funk, Jonathan, and Mendel, David, 2012, Leadville South quadrangle geologic map: Colorado Geological Survey, scale 1:24,000.

McCalpin, J.P., and Irvine, J.R., 1995, Sackungen at the Aspen Highlands Ski Area, Pitkin County, Colorado: Environmental \& Engineering Geoscience, v. 1, no. 3, p. 277-290.

McIntosh, W.C., and Chapin, C.E., 2004, Geochronology of the central Colorado volcanic field, in Cather, S.M., McIntosh, W.C., and Kelley, S.A., eds., Tectonics, geochronology, and volcanism in the Southern Rocky Mountains and Rio Grande rift: New Mexico Bureau of Mines and Mineral Resources Bulletin 160, p. 205-237.

McMillan, M.E., Heller, P.L., and Wing, S.L., 2006, History and causes of post-Laramide relief in the Rocky Mountain orogenic plateau: Geological Society of America Bulletin, v. 118 , p. 393-405.

Mears, Brainerd, Jr., 1998, Neogene normal faulting superposed on a Laramide uplift: Medicine Bow Mountains, Sierra Madre, and intervening Saratoga Valley, Wyoming and Colorado: Rocky Mountain Geology, v. 32, no. 2, p. 181-185.

Meierding, T.C., and Birkeland, P.W., 1980, Quaternary glaciation of Colorado, in Kent, H.C., and Porter, K.W., eds., Colorado geology: Rocky Mountain Association of Geologists Symposium Proceedings, Denver, p. 165-173.

Menounos, Brian, and Reasoner, M.A., 1997, Evidence for cirque glaciation in the Colorado Front Range during the Younger Dryas chronozone: Quaternary Research, v. 48 , p. $38-47$.

Merrill, G.P., 1897, A treatise on rocks, rock-weathering and soils: New York, Macmillan Company, 411 p.

Meyer, G.A., and Wells, S.G., 1997, Fire-related sedimentation events on alluvial fans, Yellowstone National Park, U.S.A.: Journal of Sedimentary Research, v. 67, p. 776-791.

Montagne, John, 1991, Cenozoic history of the Saratoga Valley, Wyoming and Colorado: Contributions to Geology, University of Wyoming, v. 29, no. 1, p. 13-70.

Montagne, John M. de la, and Barnes, W.C., 1957, Stratigraphy of the North Park Formation in the North Park area, Colorado, in Rocky Mountain Association of Geologists, Guidebook to the geology of North and Middle Parks Basin, Colorado, 1957, p. 55-60. 
Munsell Color, 1973, Munsell soil color charts: Baltimore, Md., Kollmorgen Corp., Macbeth Division.

Naeser, C.W., Izett, G.A., and Obradovich, J.D., 1980, Fissiontrack and K-Ar ages of natural glass: U.S. Geological Survey Bulletin 1489, p. 31.

Nelson, A.R., Millington, A.C., Andrews, J.T., and Nichols, H., 1979, Radiocarbon-dated upper Pleistocene glacial sequence, Fraser Valley, Colorado Front Range: Geology, v. 7, p. $410-414$.

Nelson, A.R., and Shroba, R.R., 1998, Soil relative dating of moraine and outwash-terrace sequences in the northern part of the upper Arkansas Valley, central Colorado, U.S.A.: Arctic and Alpine Research, v. 30, no. 4, p. 349-361.

North American Commission on Stratigraphic Nomenclature, 2005, North American stratigraphic code: American Association of Petroleum Geologists Bulletin, v. 89, no. 11, p. 1547-1591.

Olsen, S.N., 1982, Open- and closed-system migmatites in the Front Range, Colorado: American Journal of Science, v. 282, p. 1596-1622.

Ostenaa, D.A., Losh, S.L., and Nelson, A.R., 1980, Recurrent late Quaternary faulting in the upper Arkansas Valley near Buena Vista, Colorado [abs.]: Geological Society of America Abstracts with Programs, v. 12, no. 6, p. 300.

Ostenaa, D.A., Losh, S.L., and Nelson, A.R., 1981, Evidence for recurrent late Quaternary faulting, Sawatch fault, upper Arkansas Valley, Colorado, in Junge, W.R., Colorado tectonics, Seismicity, and Earthquake Hazards-

Proceedings and field trip guide for a symposium held in Denver, Colorado June 4-6, 1981: Colorado Geological Survey Special Publication 19, p. 27-29.

Parker, B.H., Jr., 1974a, Gold placers of Colorado: Colorado School of Mines Quarterly, v. 69, no. 3, 268 p. [book one of two books]

Parker, B.H., Jr., 1974b, Gold placers of Colorado: Colorado School of Mines Quarterly, v. 69, no. 4, 224 p. [book two of two books]

Parker, B.H., Jr., 1992, Gold panning and placering in Colorado-How and where: Colorado Geological Survey, Information Series 33, 83 p.

Perkins, M.E., Diffendal, R.F., Jr., and Voorhies, M.R., 1995, Tephrochronology of the Ash Hollow Formation (Ogallala Group)-Northern High Plains [abs.]: Geological Society of America Abstracts with Programs, v. 27, no. 3, p. 79.

Pierce, K.L., 2004, Pleistocene glaciation of the Rocky Mountains, in Gillespie, A.R., Porter, S.C., and Atwater, B.F., eds., The Quaternary Period in the United States: Amsterdam, Elsevier, p. 63-76.
Pierce, K.L., Muhs, D.R., Fosberg, M.A., Mahan, S.A., Rosenbaum, J.G., Licciardi, J.M., and Pavich, M.J., 2011, A loess-paleosol record of climate and glacial history over the past two glacial-interglacial cycles $(\sim 150 \mathrm{ka})$, southern Jackson Hole, Wyoming: Quaternary Research, v. 76, p. 119-141.

Pierson, T.C., and Costa, J.E., 1987, A rheologic classification of subaerial sediment-water flows, in Costa, J.E., and Wieczorek, G.F., eds., Debris flows / Avalanches-Process, recognition, and mitigation: Geological Society of America, Reviews in Engineering Geology, v. 7, p. 1-12.

Premo, W.R., Kellogg, K.S., Bryant, Bruce, 2007, SHRIMP $\mathrm{U}-\mathrm{Pb}$ zircon ages for Paleoproterozoic basement rocks from the northern and central Colorado Front Range-A refinement of the timing of crustal growth in the Colorado Province [abs.]: Geological Society of America Abstracts with Programs, v. 39, no. 6, p. 221.

Ray, L.L., 1940, Glacial chronology of the southern Rocky Mountains: Geological Society of America Bulletin, v. 51, p. 1851-1917.

Richmond, G.M., 1976, Pleistocene stratigraphy and chronology in the mountains of western Wyoming: in Mahaney, W.C. ed., Quaternary Stratigraphy of North America, p. 353-379.

Richmond, G.M., and Fullerton, D.S., 1986, Introduction to Quaternary glaciations in the United States of America, in Richmond, G.M., and Fullerton, D.S., eds., Quaternary glaciations in the United States of America: Quaternary Science Reviews, v. 5, p. 3-10.

Richmond, G.M., and Murphy, J.F., 1989, Preliminary Quaternary geologic map of the Dinwoody Lake area, Fremont County, Wyoming: U.S. Geological Survey Open-File Report 89-435, 2 p., scale 1:48,387.

Richmond, G.M., and Tweto, O.L., 1965, Glaciation of the Sawatch Mountains, in Schultz, C.B., and Smith, H.T.U., eds., International Association for Quaternary Research, $7^{\text {th }}$ Congress, Guidebook for Field Conference E, Northern and Middle Rocky Mountains: Lincoln, Nebraska, Academy of Sciences, p. 122-124.

Ruleman, C.A., Goehring, B.M., Mason, Cody, and Lundstrom, S.C., 2013, Late Pleistocene glacial maximum and deglaciation of the northern Sawatch Range, Mount Massive, Colorado, USA [abs.]: Geological Society of America Abstracts with Programs, v. 45, no. 7, p. 551.

Sarna-Wojcicki, A.M., Pringle, M.S., and Wijbrans, Jan, 2000, New ${ }^{40} \mathrm{Ar} /{ }^{39} \mathrm{Ar}$ age of the Bishop Tuff from multiple sites and sediment rate calibration for the Matuyama-Brunhes boundary: Journal of Geophysical Research, v. 105, p. $21,431-21,443$. 
Schildgen, Taylor, Dethier, D.P., Bierman, Paul, and Caffee, Marc, 2002, ${ }^{26} \mathrm{Al}$ and ${ }^{10} \mathrm{Be}$ dating of late Pleistocene and Holocene fill terraces - A record of fluvial deposition and incision, Colorado Front Range: Earth Surface Processes and Landforms, v. 27, p. 773-787.

Schoeneberger, P.J., Wysocki, D.A., Benham, E.C., and Soil Survey Staff, 2012, Field book for describing and sampling soils, Version 3.0: Lincoln, Nebraska, Natural Resources Conservation Service, National Soil Survey Center, 300 p., ftp://ftp-fc.sc.egov.usda.gov/NSSC/Field_Book/FieldBookVer3.pdf.

Scott, G.R., 1975, Reconnaissance geology of the Buena Vista quadrangle, Chaffee and Park Counties, Colorado: U.S. Geological Survey Miscellaneous Field Studies Map MF-657, scale 1:62,500.

Scott, G.R., Van Alstine, R.E., and Sharp, W.N, 1975, Geologic map of the Poncha Springs quadrangle, Chaffee County, Colorado: U.S. Geological Survey Miscellaneous Field Studies Map MF-658, scale 1:62,500.

Shannon, J.R., and McCalpin, J.P., 2006, Geologic map of the Maysville quadrangle, Chaffee County, Colorado: Colorado Geological Survey, Open-File Report 06-10, scale 1:24,000.

Sharp, W.D., Ludwig, K.R., Chadwick, O.A., Amundson, Ronald, and Glaser, L.L., 2003, Dating fluvial terraces by ${ }^{230} \mathrm{Th} / \mathrm{U}$ on pedogenic carbonate, Wind River Basin, Wyoming: Quaternary Research, v. 59, p. 139-150.

Shroba, R.R., 1977, Soil development in Quaternary tills, rock-glacier deposits, and taluses, southern and central Rocky Mountains: Boulder, University of Colorado, unpublished Ph.D. dissertation, $424 \mathrm{p}$.

Shroba, R.R., Bryant, Bruce, Kellogg, K.S., Theobald, P.K., and Brandt, T.R., 2010, Geologic map of the Fraser 7.5-minute quadrangle, Grand County, Colorado: U.S. Geological Survey Scientific Investigations Map 3130, 26 p., 1 sheet, scale 1:24,000.

Shroba, R.R., Rosholt, J.N., and Madole, R.F., 1983, Uraniumtrend dating and soil B horizon properties of till of Bull Lake age, North St. Vrain drainage basin, Front Range, Colorado [abs.]: Geological Society of America Abstracts with Programs, v. 15, no. 5, p. 431.

Snyder, G.L., 1980a, Geologic map of the northernmost Park Range, Sierra Madre, Jackson, and Routt Counties, Colorado: U.S. Geological Survey Miscellaneous Investigations Series Map I-1113, scale 1:48,000.

Snyder, G.L., 1980b, Geologic map of the northernmost Gore Range and southernmost northern Park Range, Grand, Jackson, and Routt Counties, Colorado: U.S. Geological Survey Miscellaneous Investigations Series Map I-1114, scale 1:48,000.
Soil Survey Staff, 1951, Soil survey manual: U.S. Department of Agriculture Handbook 18, 503 p.

Soil Survey Staff, 1999, Soil taxonomy-A basic system of soil classification for making and interpreting soil surveys: U.S. Department of Agriculture Handbook 436, 2nd ed., 869 p.

Steven, T.A., 2002, Late Cenozoic tectonic and geomorphic framework surrounding the evaporite dissolution area in west-central Colorado, in Kirkham, R.M., Scott, R.B., and Judkins, T.W., eds., Late Cenozoic evaporite tectonism and volcanism in west-central Colorado: Geological Society of America Special Paper 366, p. 15-30.

Steven, T.A., Evanoff, Emmett, and Yuhas, R.H., 1997, Middle and late Cenozoic tectonic and geomorphic development of the Front Range, Colorado, in Bolyard, D.W., and Sonnenberg, S.A., eds., Geologic history of the Colorado Front Range: Rocky Mountain Association of Geologists field-trip guidebook: Denver, Rocky Mountain Association of Geologists, p. 115-124.

Sturchio, N.C., Pierce, K.L., Murrell, M.T., and Sorey, M.L., 1994, Uranium-series ages of travertines and timing of the last glaciation in the northern Yellowstone area, WyomingMontana: Quaternary Research, v. 41, p. 265-277.

Swinehart, J.B., and Diffendal, R.F., Jr., 1995, Geologic map of Morrill County Nebraska, with a section on new ${ }^{40} \mathrm{Ar} /{ }^{39} \mathrm{Ar}$ laser fusion ash dates from the Wildcat Ridge, Nebraska: U.S. Geological Survey Miscellaneous Investigations Series Map I-2496, scale 1:62,500.

Taylor, R.B., Scott, G.R., and Wobus, R.A., 1975, Geologic map of the Howard quadrangle, central Colorado: U.S. Geological Survey Miscellaneous Investigations Series Map I-892, scale 1:62,500.

Tedford, R.H., Albright, L.B., III, Barnoksy, A.D., FerrusquiaVillafranca, Ismael, Hunt, R.M., Jr., Storer, J.E., Swisher, C.C., III, Voorhies, M.R., Webb, S.D., Whistler, D.P., 2004, Mammalian biochronology of the Arikareean through Hemphillian interval (late Oligocene through earliest Pliocene epochs), in Woodburne, M.O., ed., Late Cretaceous and Cenozoic mammals of North America: New York, NY, Columbia University Press, p. 169-231.

Thompson, R.A., Johnson, C.M., and Mehnert, H.H., 1991, Oligocene basaltic volcanism of the northern Rio Grande rift, San Luis Hills, Colorado: Journal of Geophysical Research, v. 96, p. 13577-13592.

Tweto, Ogden, 1961, Late Cenozoic events of the Leadville district and upper Arkansas Valley, Colorado: U.S. Geological Survey Professional Paper 424-B, p. B133-B135. 
Tweto, Ogden, 1974a, Reconnaissance geologic map of the Fairplay West, Mount Sherman, South Peak, and Jones Hill 7.5' quadrangles, Park, Lake, and Chaffee Counties, Colorado: U.S. Geological Survey Miscellaneous Field Studies Map MF-555, scale 1:62,500.

Tweto, Ogden, 1974b, Geologic map of the Mount Lincoln 15-minute quadrangle, Eagle, Park, and Summit Counties, Colorado: U.S. Geological Survey Miscellaneous Field Studies Map MF-556, scale 1:62,500.

Tweto, Ogden, 1974c, Geologic map and sections of the Holy Cross quadrangle, Eagle, Lake, Pitkin, and Summit Counties, Colorado: U.S. Geological Survey Miscellaneous Investigations Series Map I-830, scale 1:24,000.

Tweto, Ogden, 1975, Laramide (Late Cretaceous-Early Tertiary) orogeny in the Southern Rocky Mountains, in Curtis, B.F., ed., Cenozoic history of the Southern Rocky Mountains: Geological Society of America Memoirs 144, p. $1-44$.

Tweto, Ogden, 1978, Northern rift guide 1, Denver-Alamosa, Colorado, in Hawley, J.W., ed., Guidebook to Rio Grande rift in New Mexico and Colorado: New Mexico Bureau of Mines and Mineral Resources Circular 163, p. 13-27.

Tweto, Ogden, 1979a, The Rio Grande rift system in Colorado, in Riecker, R.E., ed., Rio Grande rift-Tectonics and magmatism: American Geophysical Union, Washington, D.C., p. 33-56.

Tweto, Ogden, 1979b, Geologic map of Colorado: U.S. Geological Survey, 2 sheets, scale 1:500,000.

Tweto, Ogden, 1980, Summary of Laramide Orogeny in Colorado, in Kent, H.C., and Porter, K.W., eds., Colorado geology: Rocky Mountain Association of Geologists Symposium Proceedings, Denver, p. 129-134.

Tweto, Ogden and Case, J.E., 1972, Gravity and magnetic features as related to geology in the Leadville 30-minute quadrangle, Colorado: U.S. Geological Survey Professional Paper 726-C, 31 p.

Tweto, Ogden, Moench, R.H., and Reed, J.C., Jr., 1978, Geologic map of the Leadville 1 degree by 2 degrees quadrangle, northwestern Colorado: U.S. Geological Survey Miscellaneous Investigations Series Map I-999, scale $1: 250,000$.

Tweto, Ogden and Reed, J.C., Jr., 1973, Reconnaissance geologic map of the Mount Elbert 15-minute quadrangle, Lake, Chaffee, and Pitkin Counties, Colorado: U.S. Geological Survey Open-File Report 73-287, scale 1:62,500.

U.S. Geological Survey Geologic Names Committee, 2010, Divisions of geologic time-Major chronostratigraphic and geochronologic units: U.S. Geological Survey Fact Sheet 2010-3059, 2 p.
Van Alstine, R.E., 1968, Tertiary trough between Arkansas and San Luis valleys, Colorado: U.S. Geological Survey Professional Paper 600-C, p. C158-C160.

Van Alstine, R.E., 1969, Geology and mineral deposits of the Poncha Springs NE quadrangle, Chaffee County, Colorado, with a section on fluorspar mines and prospects: U.S. Geological Survey Professional Paper 626, 52 p.

Van Alstine, R.E., 1974, Geology and mineral deposits of the Poncha Springs SE quadrangle, Chaffee County, Colorado: U.S. Geological Survey Professional Paper PP 829, 19 p.

Van Alstine, R.E., and Lewis, G.E, 1960, Pliocene sediments near Salida, Chaffee County, Colorado: U.S. Geological Survey Research 1960 in Short Papers in the geological sciences, Professional Paper 400-B, p. B245.

Varnes, D.J., and Cruden, D.M., 1996, Slope movement types and process, in Schuster, R.L., and Krizek, R.J., eds., Landslide investigation and mitigation: Washington, D.C., National Academy Press, Transportation Research Board Special Report 247, p. 36-75.

Varnes, D.J., Radbruch-Hall, D.H., and Savage, W.Z., 1989, Topographic and structural conditions in areas of gravitational spreading of ridges in the western United States: U.S. Geological Survey Professional Paper 1496, 28 p.

Wahrhaftig, Clyde, 1965, Stepped topography of the southern Sierra Nevada, California: Geological Society of America Bulletin, v. 76, p. 1165-1190.

Wahrhaftig, Clyde, and Cox, Alan, 1959, Rock glaciers in the Alaska Range: Geological Society of America Bulletin, v. 70, p. 383-436.

Westgate, L.G., 1905, The Twin Lakes glaciated area, Colorado: Journal of Geology, v. 13, p. 285-312.

White, S.E., 1976, Rock glaciers and block fields, review and new data: Quaternary Research, v. 6, p. 77-97.

Winkler, G.R., 1970, Sedimentology and geomorphic significance of the Bishop Conglomerate and the Browns Park Formation, eastern Uinta Mountains, Utah, Colorado, and Wyoming: Salt Lake City, University of Utah, M.S. thesis, $115 \mathrm{p}$.

Woodburne, M.O., and Swisher, C.C., Jr., 1995, Land mammal high-resolution geochronology, intercontinental overland dispersals, sea level, and vicariance, in Berggren, W.A., Kent, D.V., Aubry, M.P., and Hardenbol, Jan, eds., Geochronology, time scales and global stratigraphic correlation: Society for Sedimentary Geology, Special Publication 54, p. 335-364. 
Xu, Tianguang, Oviatt, Jack, Hubbard, Mary, 2001, Sedimentology and stratigraphy of Tertiary continental deposits of the Poncha Pass transfer zone and adjacent area, Colorado [abs.]: Geological Society of America Abstracts with Programs, v. 33, no. 6, p. 74 .

Young, N.E., Briner, J.P., Leonard, E.M., Licciardi, J.M., and Lee, Keenan, 2011, Assessing climatic and nonclimatic forcing of Pinedale glaciation and deglaciation in the western United States: Geology, v. 39, no. 2, p. 171-174.

For more information concerning this publication, contact:

Center Director, USGS Geosciences and Environmental Change

Science Center

Box 25046, Mail Stop 980

Denver, CO 80225

(303) 236-5344

Or visit the Geosciences and Environmental Change Science Center Web site at: http://gec.cr.usgs.gov/ 


\section{$\frac{\mathbb{3}}{3}$}

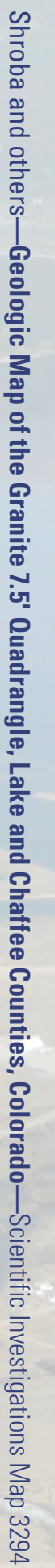

